WORKING PAPER NO. 18

Aug 1997

\title{
Inter-generational Access to Resources: Developing Criteria and Indicators
}

Carol J. Pierce Colfer, Reed L. Wadley, Emily Harwell and Ravi Prabhu

\begin{abstract}
Summary
This paper makes use of data from a methodological pre-test conducted in and around Danau Sentarum Wildlife Reserve in West Kalimantan, Indonesia. Its purpose was to contribute to the development of principles, criteria and indicators for sustainable forest management (SFM). The particular topic investigated here is "inter-generational access to resources", an issue widely deemed important - and very difficult to assess - in sustainable forest management.

The methods pre-tested are described, and earlier versions of the principles, criteria and indicators are re-evaluated, re-ordered and scored in a dual attempt:

- to develop simple, inexpensive and reliable assessment methods, and

- to contribute to our understanding of the causal links between inter-generational access to resources and sustainable forest management.
\end{abstract}

CENTER FOR INTERNATIONAL FORESTRY RESEARCH

office address: Jalan CIFOR, Situ Gede, Sindangbarang, Bogor 16680, Indonesia

mailing address: P.O. Box 6596 JKPWB, Jakarta 10065, Indonesia

tel.: +62 (251) 622622 fax: $+62(251) 622100$

email: cifor@egnet.com

$W W W:$ http://www.cgiar.org/cifor 


\section{The CGIAR System}

The Consultative Group on International Agricultural Research (CGIAR) is an informal association of 41 public and private sector donors that supports a network of sixteen international agricultural research institutes, CIFOR being the newest of these. The Group was established in 1971. The CGIAR Centers are part of a global agricultural research system which endeavour to apply international scientific capacity to solution of the problems of the world's disadvantaged people.

\section{CIFOR}

CIFOR was established under the CGIAR system in response to global concerns about the social, environmental and economic consequences of loss and degradation of forests. It operates through a series of highly decentralised partnerships with key institutions and/or individuals throughout the developing and industrialised worlds. The nature and duration of these partnerships are determined by the specific research problems being addressed. This research agenda is under constant review and is subject to change as the partners recognise new opportunities and problems. 


\section{Contents}

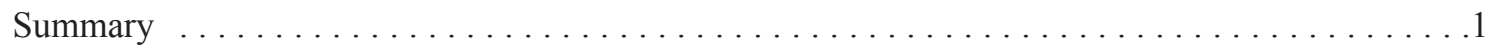

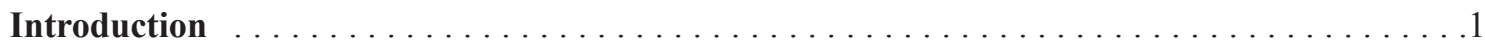

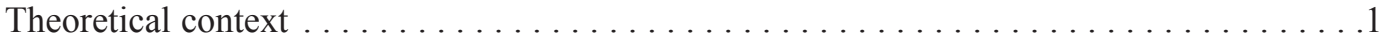

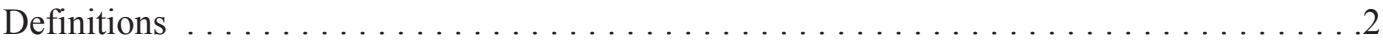

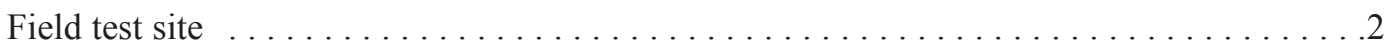

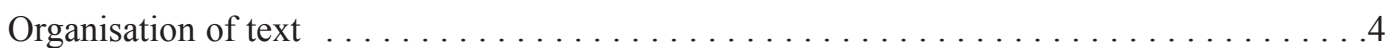

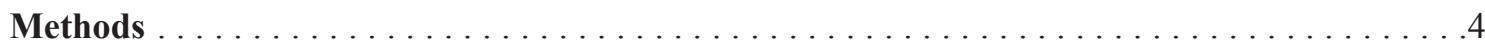

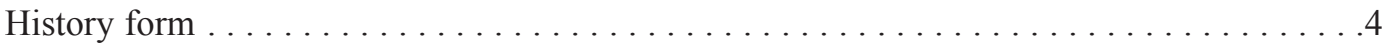

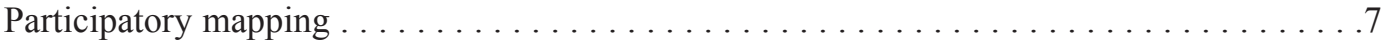

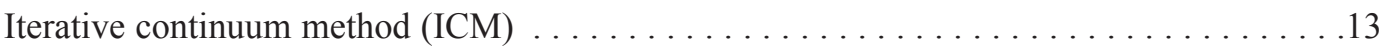

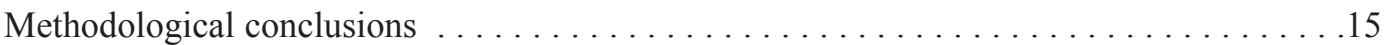

Principles, Criteria and Indicators for Assessing Inter-generational Access to Resources $\ldots .15$

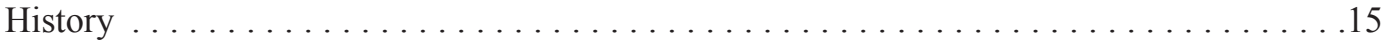

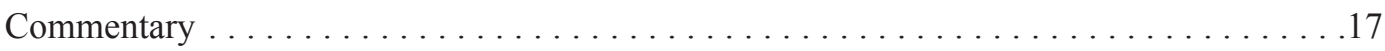

Cases from DSWR pertaining to inter-generational access to resources $\ldots \ldots \ldots \ldots \ldots 18$

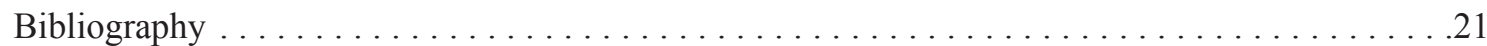

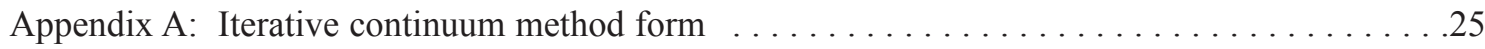

Appendix B: Preliminary steps to sustainability - security of inter-generational access

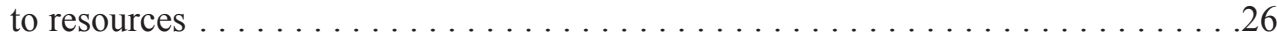

Appendix C: Cases serving as evidence in the assessment of security of inter-generational access to resources 


\title{
Inter-generational Access to Resources: Developing Criteria and Indicators
}

\author{
Carol J. Pierce Colfer, Reed L. Wadley, Emily Harwell and Ravi Prabhu ${ }^{1}$
}

\begin{abstract}
Summary
This paper makes use of data from a methodological pre-test conducted in and around Danau Sentarum Wildife Reserve in West Kalimantan, Indonesia. Its purpose was to contribute to the development of principles, criteria and indicators for sustainable forest management (SFM). The particular topic investigated here is "intergenerational access to resources", an issue widely deemed important - and very difficult to assess - in sustainable forest management.

The methods pre-tested are described, and earlier versions of the principles, criteria and indicators are reevaluated, re-ordered and scored in a dual attempt:

- to develop simple, inexpensive and reliable assessment methods, and

- to contribute to our understanding of the causal links between inter-generational access to resources and sustainable forest management.
\end{abstract}

\section{INTRODUCTION}

The fundamental impetus to the research reported here was a widely recognised need to be able to assess intergenerational access to resources simply, inexpensively and reliably. Although our research effort was initially sparked by an interest in timber certification, we quickly found a significant group of other would-be users forest managers, government policy makers, scientists, donors, even local communities - interested in enhancing the sustainability of global forest management. As we worked on developing methods, we also realised there was a more fundamental question: Why, and by what means, is inter-generational access to resources important for sustainable forest management (SFM)?
The analysis provided in this paper focuses on the first issue (methods), but we have tried to advance our understanding of the causal links, as well. Still a great deal remains to be done.

\section{Theoretical Context}

The above questions arose in the context of an ongoing effort to assess sustainable forest management (see Prabhu et al. 1996). Part of this process has focused on identifying or defining principles, criteria, indicators and verifiers - organised in an hierarchical fashion ${ }^{2}-$ that will allow us to assess forest conditions (including those of forest people) in a simple, cost effective and reliable way. We hope, in this way, to make assess-

1 Colfer is Social Science co-ordinator for CIFOR's project Assessing Sustainable Forest Management: Testing Criteria and Indicators. Wadley has worked on the same project as a consultant and is a doctoral candidate in the Department of Anthropology, Arizona State University. Harwell is a doctoral candidate at Yale University doing her research in the DSWR area. Ravi Prabhu is the team leader of the CIFOR project and a forester. We would also like to express our gratitude to Lini Wollenberg who carefully critiqued earlier drafts of this paper. We accept sole responsibility for any remaining errors or misinterpretations.

2 The organisation of these issues into a hierarchy has been the topic of considerable discussion. (Lammerts van Bueren and Blom [1997] provide a thorough introduction to the hierarchical approach.) We remain uncertain that a hierarchical perspective is the most appropriate, and we are considering the use of networks as perhaps more appropriate in the long run. For the purposes of this paper, however, we continue to use a hierarchical approach, for lack of anything better (see Conclusion). 
ments cost effective enough so that important stakeholders - governments, scientists, donors, project and forest managers, and ideally even local people - will routinely use them, thereby contributing to improvements in forest management. From our perspective, the conditions of human beings living in and around forest areas constitute important elements of sustainable forest management.

The importance of local people's security of intergenerational access to resources was identified in six recent CIFOR field tests of criteria and indicators (C\&I) for sustainable forest management (Prabhu et al. 1996, 1997; see also Colfer et al. 1995) - in Germany, Indonesia, Côte d'Ivoire, Brazil, Austria and Cameroon. This issue has also been debated in numerous other scholarly studies (e.g., Fortmann and Bruce 1988; Ostrom 1990; Lynch and Alcorn 1994; Rose 1994; Besley 1995; Grigsby 1995; Lueck 1995). Yet we all (CIFOR personnel and test team members) felt real dissatisfaction with our ability to assess the $\mathrm{C} \& \mathrm{I}$ selected by the teams. We also felt uncertain about the causal links between security of access and sustainable forest management. Security of inter-generational access to resources seemed too difficult to determine reliably in the short amount of time typically available.

In response to these problems, we decided to focus some research on these two issues: developing simple methods, and improving our understanding of the role of security of inter-generational access to resources (among other things) in forest management.

\section{Definitions}

What do we mean by "security of inter-generational access to resources"? The most common examples cited by CIFOR team members included security of land tenure, use rights for forest products and fair distribution of forest benefits. ${ }^{3}$ The meaning of "intergenerational" is quite obvious in the Indonesian con- text. The resources in question are for the benefit of both this, and subsequent, generations (see Becker 1997, for a brief philosophical discussion of this issue). "Security" refers to a reasonable certainty that the future will not involve a significant reduction in people's access.

"Access" includes the following:

- the resource remains (sufficient quantity and quality), ${ }^{5}$

- the people can use it, as needed or to the same extent as in the past, ${ }^{6}$

- "fairness" exists in regulations governing its use and distribution.

By "resources", we refer to natural resources, such as forests and their products, streams, lakes, agricultural lands, fisheries, anything in nature that has or could have a productive potential and/or provide ecological or cultural services - in forested landscapes.

\section{Field Test Site}

A preliminary step in the pursuit of these goals involved a pre-test of three methods ${ }^{7}$ in and around the Danau Sentarum Wildlife Reserve (DSWR) in West Kalimantan, Indonesia (Figure 1). DSWR was originally gazetted as an 80,000 ha wildlife reserve because of its ecological uniqueness. It is an area of seasonally flooded, black water lakes, in the remote interior of Borneo near the border with Malaysia. During the past couple of years considerable effort has been devoted to expanding the boundary to include the hills to the east of the reserve; more recently efforts have been made to expand it northwards as well (where oil palm plantations were being planned in DSWR's buffer zone area). This would result in a reserve of 197,000 ha.

3 The fact that there are many interpretations of "fairness," reflecting real differences in people's perceptions and understandings, complicates the issue. See, e.g., Prakash and Thompson (1994) or Farmer and Tiefenthaler (1995) for fuller discussions.

4 The meaning of "inter-generational" has proved more complicated in Cameroon, where there is rather dramatic competition, even antagonism, between different generations, between the young and the old - something rare or under-stated in the Indonesian context.

5 One could argue that this issue can be left to the ecologists. However, our own perspective is that local people are likely to have important responsibilities in maintaining that resource. Where people have developed mechanisms for maintaining a resource, its condition is likely to be better.

6 As with many criteria and indicators there are potential conflicts. If the population has risen drastically, for instance, the same resource base may no longer support previous levels of use. This in turn will affect the first quality of "access." It is also a "red flag" relating to sustainability.

7 We actually pre-tested eight methods, but the remaining five dealt with other C\&I of relevance to people in forests (participation in forest management and a "conservation ethic"). See Colfer and Wadley 1996 and Colfer et al. 1996. 
Figure 1. Map of Danau Sentarum Wildlife Reserve (DSWR), showing Traditional Territories
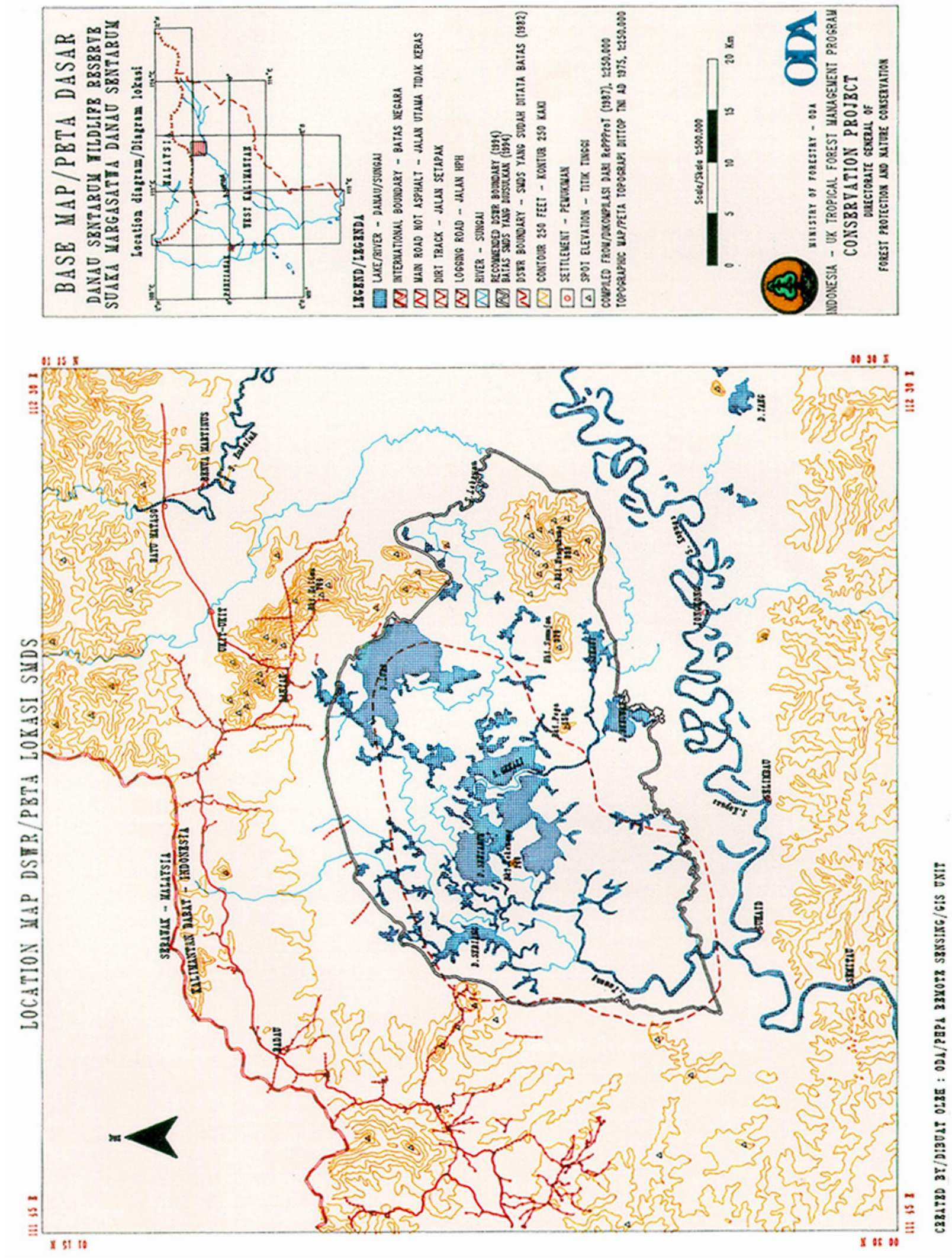
This site was chosen for our pre-test for several reasons:

- Three of the authors spent a total of six years conducting ethnographic research in the area (1992 1997).

- We had access to over 130 reports from an ongoing conservation project there, along with results of our own studies.

- The area represented a variety of purported managers, including local people, conservation managers and timber concessionaires.

- We anticipated considerable variation in local people's security of access to resources, based on their different resource use, different lengths of residence in their communities, and different potential conflicts with other stakeholders.

The primary "forest actors" in this area include Muslim Melayu fisherfolk who live in the seasonally flooded core of the reserve, Christian and animist Iban swidden cultivators who live in the surrounding hills and, to a much lesser degree, forest workers. These two main groups inhabit ecologically very different habitats and have significantly different natural resource management systems. Other important stakeholders include residents of the larger, Melayu "mother villages" along the Kapuas river, traders, timber concession holders, timber workers, the conservation project and local government. We were also cognisant of the potentially different concerns of men vs. women, old vs. young, rich vs. poor, and newcomers vs. old-timers (see particularly Nurse et al. 1995 or Wollenberg 1996).

We focused on four communities: ${ }^{9}$ the Melayu communities of Nanga Kedebu' and Danau Seluang, and the Iban communities of Wong Garai and Bemban. Because of logistical problems resulting in an incomplete pre-test in Bemban, we pre-tested some of our methods in the Iban community of Kelayang.

\section{Organisation of Text}

In the following section we introduce and evaluate our methods. We then discuss several iterations of principles, criteria and indicators on the topic of intergenerational access to resources. In this discussion we are interested both in the proper wording and the hierarchical status of criteria and indicators (to simplify assessment as much as possible), and in providing cases which exemplify field-based evidence pertaining to these C\&I. The purpose of the latter is to shed additional light on the question raised at the beginning of this Introduction: Why and by what means is intergenerational access to resources important for sustainable forest management? In other words, what are the causal links between these issues and sustainable forest management? This section concludes with a discussion of our scoring of the qualitative cases pertaining to each indicator. ${ }^{10}$ With improvement this could allow us to quantify our assessments of these criteria and their indicators, and help us come to a decision on the sustainability of the management of a particular forest and its people's inter-generational access to resources.

\section{METHODS}

We selected two methods, and developed a third, to pre-test: a history form, participatory mapping, and the "Iterative Continuum Method" (or ICM). Each of these is described below, with comments on our related experience, and evaluation of its utility for cost-effective assessment of inter-generational access to resources. The methods are presented in an order that reflects increasing expertise needed by the assessor.

\section{History Form}

Tainter (1995) and Vayda (1996), among others, have recently argued for the important role that history must play in any attempt to address sustainability issues. Sustainability, by definition, has a temporal component. Similarly, "inter-generational access to resources" has a time frame built into it. By using the history form, we hoped to gain some sense of the sweep of history within the area; we hoped that looking backward might be helpful to us in the much more difficult task of looking forward. We also hoped that looking at the current situation with some understanding of past events would help us, as Vayda (1996) argues, to understand some of the "causes" behind the present situation. Finally, we hoped that the history form would serve as

\footnotetext{
"Forest actors" (discussed in detail in Colfer 1995) are those people who, ethically and pragmatically, need greater attention from forest managers. This may be because they have not been treated "fairly" and/or because they have a greater likelihood of directly affecting the forest than do other stakeholders.

9 Pseudonyms have been created for the communities and timber concessions in and around Danau Sentarum Wildlife Reserve to protect the privacy of individuals who have shared their perspectives with us.

10 We are cognisant of the pertinence of Becker's criticism of scoring systems. She says " $[t]$ he problem with scoring systems is that they pretend objectivity and uniformity, while the choice of components and their assigned weights is highly subjective, and the aggregation of different spatial, temporal and sectoral dimensions is often not meaningful.” (1997:32).
} 
a catalyst to discussions which in turn would help us understand the dynamics of factors affecting intergenerational access to resources.

This method was the simplest and most straightforward of the three. We simply filled two sides of a piece of paper with dates, starting in 1920, with a line next to each date (similar to the "time lines" described in the Participatory Rural Appraisal Handbook 1990). We then asked individuals and groups in our study villages to tell us important events in the community's history (shown on Table 1). ${ }^{11}$ As we learned more, we were able to prompt people with known dates and to help them estimate unknown dates, since the use of dates is not common in the Lakes area. These we put on the form. This helped us gain historical perspective on natural disasters, warfare, the arrival of significant outsiders like timber concessionaires and the conservation project, adoption or development of important new technology, etc.

Table 1. DSWR History, as obtained from local communities

$[\mathrm{BR}=$ Bukit Rancong, DS = Danau Seluang, NK = Nanga Kedebu', K = Kelayang, B = Bemban; PD = Pulau Duri'; WG = Wong Garai; RW = Other Sources]

The Dutch to Putussibau (regency capitol) sometime before the beginning of the century. (NK)

\begin{tabular}{|c|c|}
\hline DATE & EVENT \\
\hline 1830 s & Iban settled north of DSWR (Emperan, RW) \\
\hline 1855 & Dutch and Iban made first contact (RW) \\
\hline $1860 \mathrm{~s}$ & Jinak, founding ancestor of WG, settles in Lubok Rian area (WG) \\
\hline $1870 \mathrm{~s}$ & Jinak requests land/makes formal peace with Banuaka’ Labian of Leboyan for pres. site \\
\hline $1870 \mathrm{~s}$ & $\begin{array}{l}\text { Dutch establish posts at Ng. Kantu', Ng. Badau, Pulau Majang, Pangkalang Pesaya, Genting Durian and Lubok Rian } \\
\text { (RW, WG) }\end{array}$ \\
\hline $1880 \mathrm{~s}$ & Dutch establish posts at Guntul, Bakul and Jejawe' (WG, RW) \\
\hline $1880 \mathrm{~s}$ & Iban help Banuaka’ Labian stop raid by Selimbau Melayu (WG) \\
\hline 1886 & Dutch-brokered peace between Iban and Banuaka' (WG, RW) \\
\hline 1886 & 3 longhouses in WG terr. destroyed by Charles Brooke's punitive raid on Iban (WG,RW) \\
\hline $1890 \mathrm{~s}$ & Jinak pioneers Melingkong (Menyukung, DSWR maps), dies of dysentery (RW,WG) \\
\hline 1908 & Dutch Capuchin missionaries set up mission, Lubok Rian (WG,RW) \\
\hline $1910 \mathrm{~s}$ & Iban leaders arrested by Dutch, made to plant rubber in Semitau for paying taxes (WG) \\
\hline 1917 & Dutch move upper Leboyan Iban to prevent raids to Sarawak; WG gave land. (WG,RW) \\
\hline 1917 & WG people return from Melingkong, under apparent pressure from Dutch (WG) \\
\hline 1920 s & Dutch est. wet rice proj. on WG land, but another longhouse benefits (WG,RW) \\
\hline 1921 & Missionaries move to Benua Martinus because Iban refuse to convert (WG,RW) \\
\hline 1928 & National Youth Vow (Oct. 28) \\
\hline 1930 & Tungu Muda resigns as Iban leader; Budit becomes new Iban leader (temenggung, K) \\
\hline 1933 & DS first settled (approximate) \\
\hline $41-45$ & Shortages of salt and market cloth, gifts of blankets from Japan. occupation (WG, RW) \\
\hline 1943 & Dol, an NK resident and company employee, was born (NK) \\
\hline 1944 & Iban harassed the Japanese occupying the area, by stealing from them (NK) \\
\hline 1945 & WG men raid Japan. post at Engkelili, Sarawak w. knives/spears; no deaths (WG, RW) \\
\hline 1945 & Indonesian Independence proclaimed (August 17) \\
\hline 1951 & Big flood (B) \\
\hline 1952 & Sembar Dewa becomes village head $(\mathrm{K})$ \\
\hline 1953 & Longhouse moved across the river from current location $(\mathrm{K})$ \\
\hline 1956 & Population: 7 households (B) \\
\hline 1960 & Dol moved to NK \\
\hline 1961 & New reg.: no gill nets when water is low (if a particular stick is visible - DS) \\
\hline 1962 & Population: six households $(\mathrm{K})$ \\
\hline 1962 & Beginning of Indonesia-Malaysia Confrontation, more military in area(WG,RW) \\
\hline 1963 & Big flood (DS)' Lots of fish, very few people because of the Confrontation/Malaysia (NK) \\
\hline 1963 & Big flood; economic difficulties for 5 months; confrontation with Malaysia $(\mathrm{K})$ \\
\hline 1965 & Population: 12 households; Undom became village head $(\mathrm{K})$ \\
\hline $65-70 \mathrm{~s}$ & Communist insurgency; some WG men in civil defence force, intelligence units (WG, RW) \\
\hline $65-70 \mathrm{~s}$ & Four Chinese families in Lubok Rian are moved to Semitau (WG) \\
\hline
\end{tabular}

11 Iban history, particularly relating to Wong Garai in Table 1, is more complete than could have been accomplished within the one month field period. Wadley had already investigated Iban history, and his more general knowledge is included here simply because it was often impossible to separate previous from newly acquired knowledge. 
Table 1. DSWR History, as obtained from local communities (continued)

\begin{tabular}{|c|c|}
\hline DATE & EVENT \\
\hline $65-70 \mathrm{~s}$ & Contact betw. Iban and Mil. form, later useful in logging concession negotiations (WG) \\
\hline $65-70 \mathrm{~s}$ & Melayu first settle permanently in the Lakes area (WG) \\
\hline 1966 & Defeat of the Communist Party (11 March) \\
\hline 1966 & People began to settle Toman (3-4 households; K) \\
\hline 1968 & Bayang became village head $(\mathrm{K})$ \\
\hline 1968 & Abandoned longhouse after 12 people died there within 8 years (WG) \\
\hline 1969 & Ex head fisher moved to DS; there were 20 households \\
\hline 1969 & Planted 600 rubber trees, 200 remained after flood $(\mathrm{K})$ \\
\hline 1971 & Indonesian soldiers stayed at B, fighting Communists (B) \\
\hline 1972 & Long drought (DS); Long drought (NK); soldiers still at B \\
\hline 1973 & A predecessor to current concessionaires arrived (NK); one soldier still at B \\
\hline 1973 & P.T. Panggau Liban gets permission to log in the area $(\mathrm{K})$ \\
\hline 1974 & P.T. Panggau Liban begins logging (K; Lanjak) \\
\hline 1974 & Letter from county commissioner confirms county borders (Bakakak, Lanjak, Cincin) \\
\hline 1974 & Wong Garai becomes officially Protestant (WG); increase from 7 to 9 households (WG) \\
\hline 1975 & Longhouse moves to Lubok Ngkrutak $(\mathrm{K})$ \\
\hline $75-79$ & Wet rice project at WG, sponsored by West German church with "motivators" (WG) \\
\hline 1978 & Area Northeast of DS logged \\
\hline 1979 & Longhouse moves to Lubuk Mpurung; elem. school opens; 8 die in epidemic $(\mathrm{K})$ \\
\hline 1979 & First elementary school built to serve WG and Sawah (WG) \\
\hline 1980 & [sometime in 80s Batang Lengkok area burned - DS] \\
\hline 1980 & P.T. Hutan Hebat came to NK; First outboard motor comes to K \\
\hline 1981 & P.T. Hutan Hebat began operation - DS; Longhouse moves to current location (K) \\
\hline 1982 & Long drought, and a fish poisoning incident on the Belitung Hulu river - DS \\
\hline 1982 & Long drought, only one household has enough rice; others subsist on cassava (WG) \\
\hline 1982 & Big flood $(\mathrm{K})$ \\
\hline 1983 & Big Flood (fish poisoning incidents, 250 Melayu arrested for retributionary poisoning - DS \\
\hline 1984 & Electricity comes to the village; rice is in short supply $(\mathrm{K})$; Big drought $(\mathrm{B})$ \\
\hline 1984 & P.T. Militer came to Pulau Duri' area (Hutan Hebat is subcontractor here) (P.T. Militer) \\
\hline 1985 & Big Flood (DS); Big Flood (NK); birth control becomes available, Protestants come (K) \\
\hline 1986 & Population: 18 households, Enyang becomes village head $(\mathrm{K})$ \\
\hline 1986 & Longhouse burned (12/5, 10 AM; B); arrival of P.T. Hutan Hebat (B) \\
\hline 1987 & B got an elementary school (B); Subcontractor of P.T. Hutan Hebat began cutting (B) \\
\hline 1987 & WG man elected to Regency Legislature for 5 year term \\
\hline 1988 & $\mathrm{~K}$ becomes part of a multi-community village; Kacung becomes village head (K) \\
\hline 1988 & Empaing, Patih and longhouse headman die in flood (WG) \\
\hline 1989 & Concessionaire speedboat kills local man; fined Rp. 10 mill., received $3(\mathrm{~K})$ \\
\hline 1989 & B became a community within the village of Pulau Duri' (B) \\
\hline 1990 & Nearby villages begin using jermal padat; Timber replanting camp opens (TPTI, K) \\
\hline 1990 & Got a teacher $(\mathrm{B})$ \\
\hline 1991 & End of P. T. Hutan Hebat logging near DS \\
\hline 1991 & Move to current WG longhouse; now 12 households (WG) \\
\hline 1991 & Completion of government rod, passing thru WG territory (WG) \\
\hline 1992 & Conservation Project began, DSWR; Begin improved walkway, church (K) \\
\hline 1992 & Forest fires destroy rattan, wood and over 500 bees' nests (DS); Colfer to B \\
\hline 1992 & Wadley begins research in Lubok Rian and Wong Garai \\
\hline 1993 & School completed (NK); Conservation Project field Center completed (BR) \\
\hline 1994 & Fish poisoning from Lanjak, with distant effects (DS;NK;BR) \\
\hline 1994 & Sub-contractor of Hutan Hebat did second cutting of same area, paid Rp 1.5 mill. (B) \\
\hline 1994 & Burning by P.T. Militer of the logs it had brought to its own log dump (photo/Lanjak) \\
\hline 1994 & Village boundary with Ukit Ukit fixed at Encawit (WG) \\
\hline 1995 & Lanjak treaty among DSWR vill. (no fish poison, electric fishing or jermal) \\
\hline 1995 & Teacher came (NK); Big wind caused damage $(12 / 95-1 / 96, \mathrm{NK})$ \\
\hline 1995 & Population: 25 households, selected for government's "left behind villages" program (K) \\
\hline 1995 & Began selling handicrafts to conservation project (B) \\
\hline 1995 & Conflict between Hutan Hebat and B, regarding compensation for forest cut, damage (PD) \\
\hline 1996 & Tayak - Dayong dispute over use of jermal padat in shared lake; 50 households (DS) \\
\hline 1996 & Built village community centre $(\mathrm{K})$ \\
\hline 1996 & Population: 17 households (B) \\
\hline 1996 & Construction irrigation dam and canals begun on WG land (WG) \\
\hline
\end{tabular}


The form was useful in a general sense, in that it did serve as a catalyst for discussion; and it gave us useful dates, like the timber companies' arrival. However, people's inexperience in dealing with dates was a significant constraint to its utility. The people typically had no idea when particular events happened; and assigning dates required long discussions about what event preceded what other event. ${ }^{12}$ In each village, it was also necessary to seek out a group which included both old people (who were least likely to be comfortable with dates) and young people (who were better with dates but knew little about history). The locally recruited assistants were not much help in this endeavour, except as translators when needed. Using this method, assessors basically served as record keepers and analysts. It was simple, reliable (with cross checking) and cost effective, but did not provide sufficient information to satisfy our desire for a historical perspective. ${ }^{13}$

\section{Participatory Mapping ${ }^{14}$}

Participatory mapping was selected to pre-test because of our sense that residents were likely to be more forthcoming about boundaries, regulations, sanctions and conflicts - often sensitive topics - when confronted with a visual image than they might be when asked direct questions. We hoped to be able to get this kind of information over informal discussions about the maps and in walks through the area with local residents.

An important activity within the Conservation Project of the U.K. Department for International Development (DfID) was the participatory mapping of traditional use zones in and around DSWR. The spatial extent of community claims to forest and lake areas was mapped in a participatory fashion, between 1994 and 1997, by Dennis and Erman (1997). An array of techniques was used in the process: sketch mapping, surveying with a global positioning system (or GPS), and interpretation of radar and satellite imagery and aerial photography. Considerable time was spent incorporating the results of the community-level mapping into a GIS.
For use in the field, these boundaries were plotted on a base map at a scale of 1:75,000. The relevant areas were enlarged and photocopied in black and white. The maps requested had to show sufficient topography to facilitate recognition by the local communities. Unfortunately, due to complex topography, a surfeit of place names and lack of colour, the maps proved too difficult to interpret. This situation was resolved in the field by simplifying the maps (hand-drawing, adding colour).

Wadley, without access to the above maps (Wong Garai being on the periphery of DSWR), began with his own hand-drawn maps. He attempted some surveys of forest sites using a GPS unit, but was unable to get reliable readings because the forest cover blocked the signals (cf. Sirait et al. 1994 or Momberg et al. 1996 on the use of this technique).

In using the maps, we first asked people to identify locations from which they gathered various forest products. In the course of the discussions, the issues of indigenous management practices, access and use rights, historical trends and conflicts emerged as well. We used the maps in a variety of contexts, with various kinds of users and stakeholders. Local people were interested in the maps (partly in finding errors in them), and in many cases enjoyed pointing out areas with different uses, different histories, conflicting claims, etc. Both the maps and the accompanying excursions into community territories to see the resources about which access was to be assessed were important. Stimulated by a visual representation of the resource contexts themselves, people discussed related issues more fully.

In Danau Seluang, for instance, we were able to get a fairly clear view (Figure 2) of logged and burned areas, areas where rattan grew abundantly, and areas of comparatively "good forest" (including locally protected areas). Excursions into the forest to check the maps prompted discussions of conflicts among adjacent villages, different perceptions of boundaries and the bases of historical claims to land and other resources. Indeed, the inclusion by Danau Seluang residents of the bamboo and protected areas to the east in their territory reflects differing perceptions by this community and the adjacent Iban community. ${ }^{15}$

12 There are techniques, particularly within the field of human demography, for constructing local calendars, some of which we used, but to do this properly is often quite time consuming.

13 A probable improvement on our history form was seen on a village wall toward the end of the pre-test. It is described as "trend lines" in the Participatory Rural Appraisal Handbook (1990). This method includes population figures along with significant events in a graph format. We are currently testing these trend lines as assessment tools in East Kalimantan and Cameroon.

14 This type of method is also described in Bruce (1989), the Participatory Rural Appraisal Handbook (1990), Carter (1996), Momberg et al. (1996), Pandey et al. (1997) and others. The Asia Forest Network has also put out a series of cases, many of which have excellent examples of the uses of this type of map (e.g. Poffenberger and McGean 1993a, 1993b; Poffenberger et al. 1995, 1996; Chatterji et al. 1996). See also Lightfoot et al. (1991) for other approaches with similar goals.

15 Dennis (pers. comm. May 1997) was able to make a return field visit to investigate this more thoroughly. She found that rights vary in this area by season, and that there is no apparent conflict between these two communities and their shared use of a common area. 


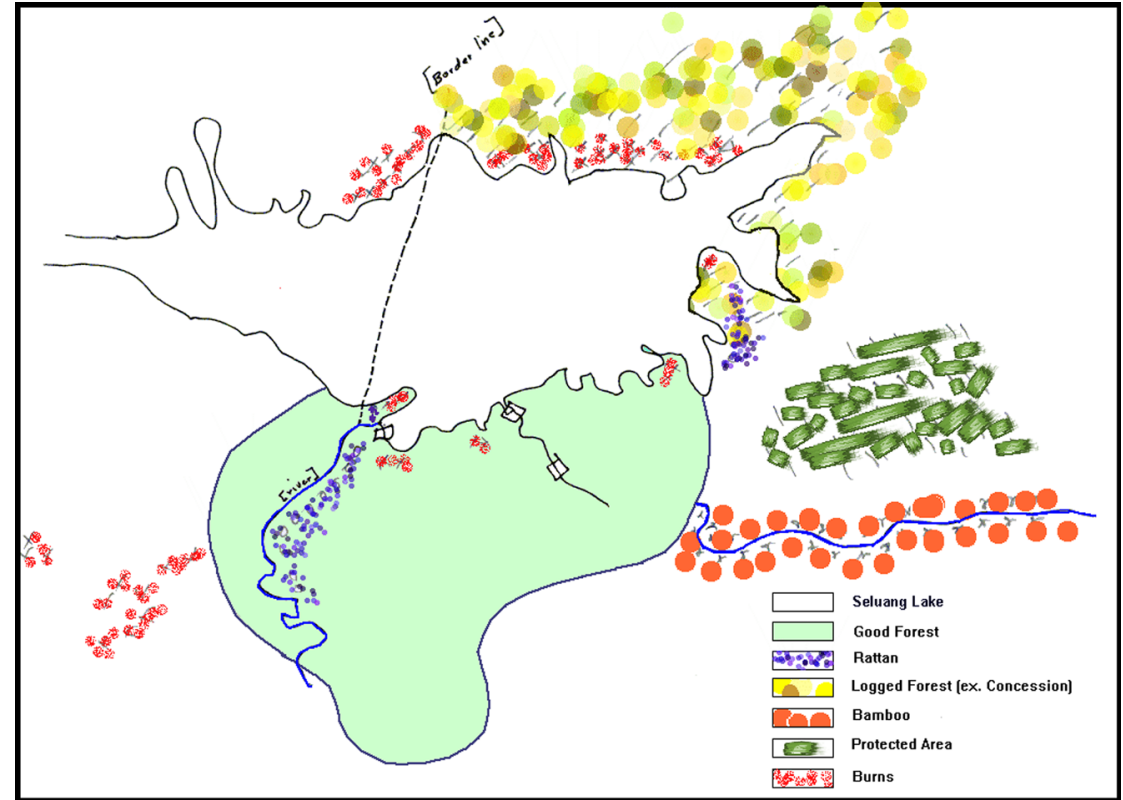

Figure 2. Danau Seluang territorial map

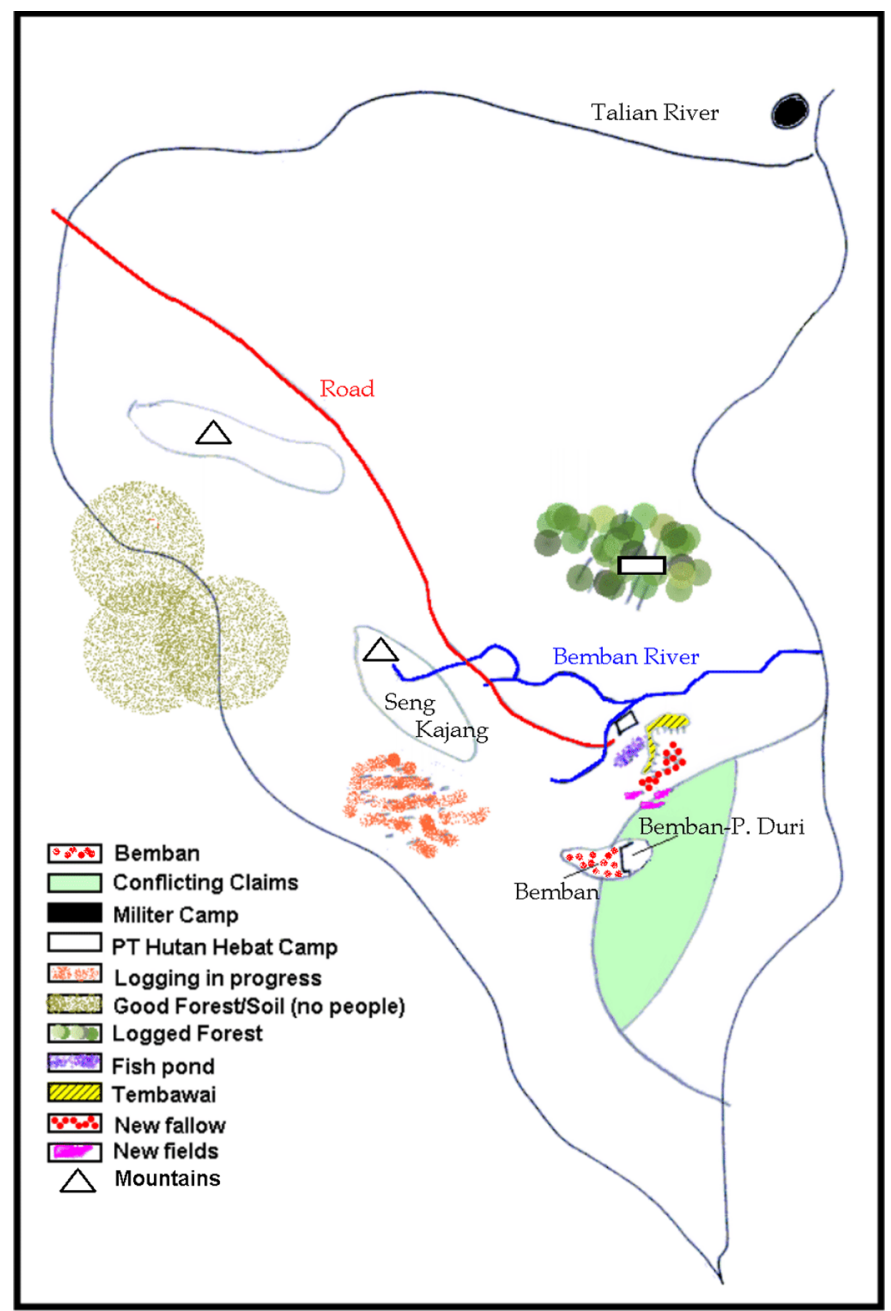

Figure 3. Bemban territorial map
With our simplified map, in Nanga (Ng.) Kedebu', we focused on non-timber forest products (NTFPs). In Danau Seluang, we had found only rattan mentioned consistently as an important NTFP. Three outings convinced us that the Melayu were not using many other NTFPs. This conclusion is consistent with 1992-93 household record-keeping data from this location. ${ }^{16}$

In Bemban, we found the method useful for eliciting historical data on settlement of the community, locations of timber camps and logging activities, and local types of land use (Figure 3). It also prompted much discussion of conflicts that had occurred between the community and various outsiders (plantation owners, other villages, timber concessionaires). The people of Kelayang, sparked by Conservation Project interest, had made their own map, on which we were able to build. Again, the mapping exercise elicited areas of resource use and conflict, and different land uses and histories.

Because of Wadley's extensive experience in Wong Garai, we were able to elicit more detailed information on the extent of the traditional use area and the present area of the longhouse's effective control (Figure 4). In going over the list of specially preserved forest and old longhouse sites originally collected by Wadley (Figure 5), he asked about the kinds of tree species used by the Iban (Table 2). The list is not exhaustive, but indicates the variety of plant resources managed and exploited by the Iban and the importance of these specially preserved areas of forest in the Iban agroforestry system. ${ }^{17}$

16 These data showed rattan as the most important forest product, accounting for 54 per cent of the products recorded as collected from the surrounding forests. The other products recorded included 16 types of wood, one kind of bark and two kinds of shingles (Colfer et al. 1993).

17 A more intensive inventory survey would likely have produced far more known plant resources (see e.g., Bernstein et al. n.d.). Hanne Christiansen (n.d.) has documented an Iban lexicon of some 2,000 plant species and reports that in one longhouse at least 127 families of plants are known and regularly used. 


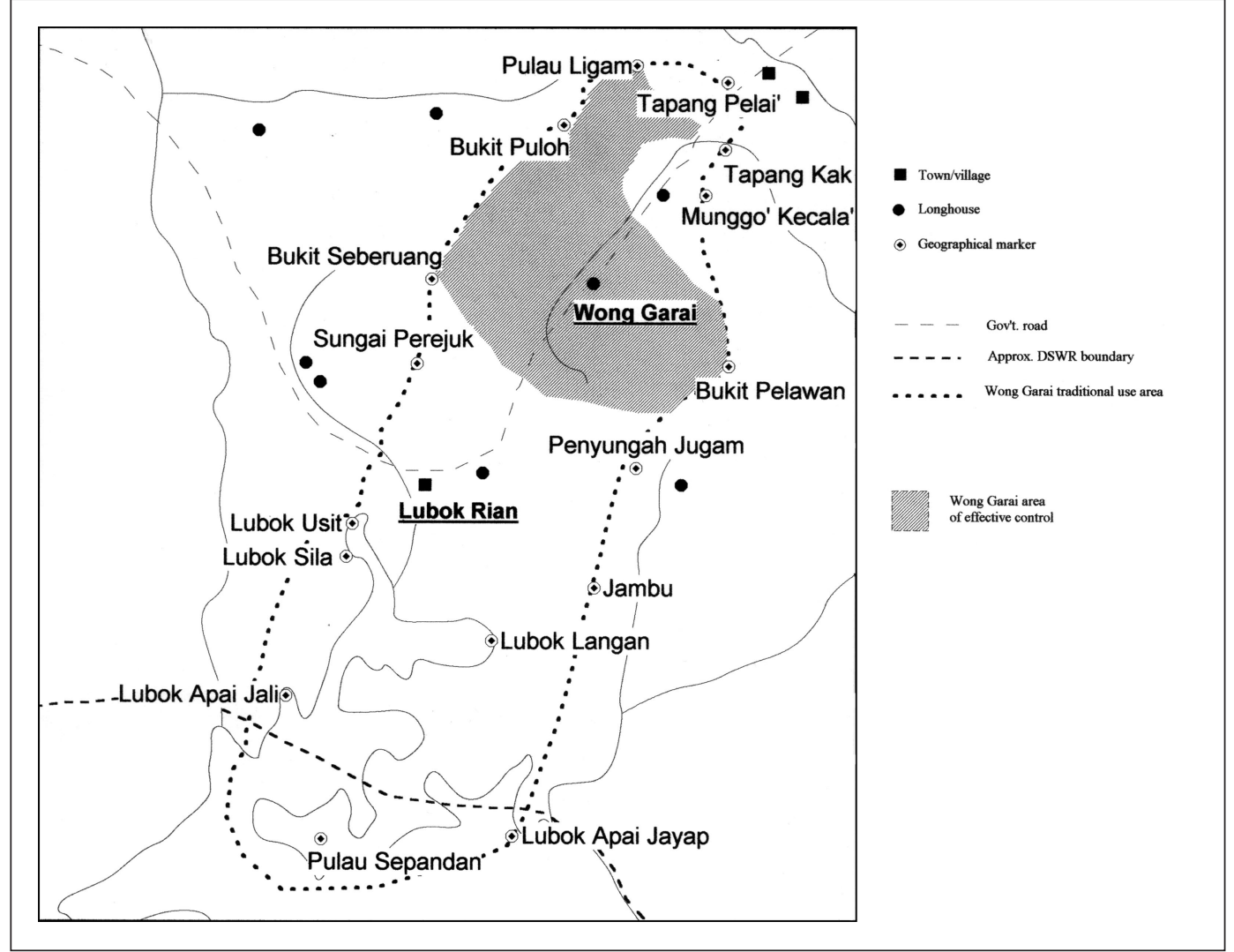

Figure 4. Areas of traditional use and effective control, Wong Garai

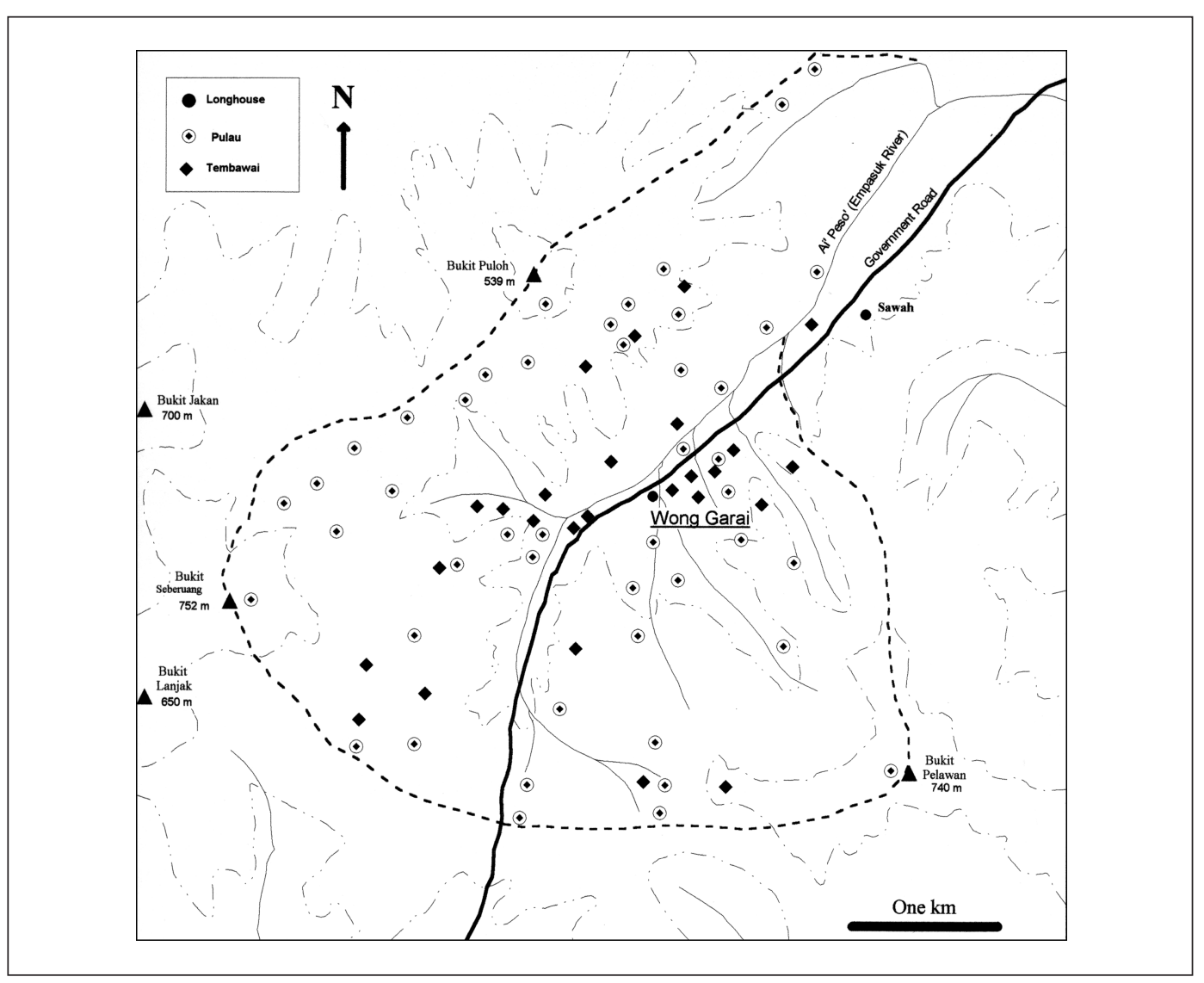

Figure 5. Specially preserved forest (Pulau) and old longhouse sites (Tembawai), Wong Garai 
Table 2. Iban Plant Resources found in Specially Preserved Forest

\begin{tabular}{|c|c|c|c|c|c|}
\hline \multicolumn{4}{|c|}{ Plant } & \multicolumn{2}{|c|}{ Found in No. of } \\
\hline Iban name & Latin name & English name & Use & Tembawai* & Pulau** \\
\hline anyang & & & fruit & 2 & \\
\hline asam & Mangifera spp. & mango & fruit & & 3 \\
\hline asam panas & Mangifera spp. (?) & mango & fruit & & 2 \\
\hline & Gigantochloa scortechinii (?) & bamboo & constr. & 2 & 3 \\
\hline baron & Mezzettia spp. & & lumber & & 1 \\
\hline belimbing & Averrhoa bilimbi & starfruit & fruit & 1 & \\
\hline bemban & Clinogyne dichotoma & reed & weaving & & 1 \\
\hline berangan & Castanopsis spp. & "chestnut" & fruit & & 4 \\
\hline berangan tadoh & Castanopsis spp. & "chestnut" & fruit & 3 & \\
\hline betong & Dendrocalamus spp. & bamboo & constr. & 2 & \\
\hline binjai & Mangifera lagenifera & mango & fruit & 1 & \\
\hline bukoh & Artocarpus spp. & jackfruit & fruit & 10 & 5 \\
\hline buloh & Bambusa spp. & bamboo & constr. & 1 & 5 \\
\hline bunut & Calophyllum spp. & & bark & & 1 \\
\hline daun tubo' & Pycnarrhena tumefacta & vine & cooking & 1 & \\
\hline dedabai & Canarium patentinervium & & fruit & & 1 \\
\hline empelam & Mangifera indica & mango & fruit & 3 & 1 \\
\hline empile’ & Lithocarpus spp. & & bark & 1 & 9 \\
\hline engkabang & Shorea macrophylla & illipe & fruit & 4 & 2 \\
\hline engkala' & Litsea garcia & & fruit & & 1 \\
\hline engkandeh & Garcinia spp. & & fruit & 1 & \\
\hline engkelili & Xylopia spp. & & fruit & 1 & \\
\hline engkeranje' & Dialium spp. & & fruit & 4 & 2 \\
\hline engkue’ & Nephelium spp. (?) & & fruit & 1 & 2 \\
\hline entawa' & Artocarpus spp. & & fruit & 1 & \\
\hline enteli & Pygeum spp. & & bark & 1 & \\
\hline entibap & Arenga spp. & palm & cabbage & & 1 \\
\hline getah & Hevea brasiliensis & rubber & latex & 10 & 6 \\
\hline ijuk & Arenga pinnata & palm & palm wine & 6 & 3 \\
\hline inyak & Cocos nucifera & coconut & fruit & 1 & \\
\hline ipoh & Antiaria toxicaria & & poison & & 1 \\
\hline isu & Durio spp. & durian & fruit & & 1 \\
\hline jambu & Eugenia spp. & guava & fruit & 1 & 1 \\
\hline jelentik & Baccaurea spp. & & fruit & 1 & \\
\hline kapok & Ceiba pentandra & silk cotton & cotton & 1 & \\
\hline kara’ & Ficus spp. & fig & fruit & 1 & 1 \\
\hline keladan & Dryobalanops spp. & & lumber & & 6 \\
\hline kemantan & Mangifera foetidal & & & & \\
\hline & Dacryodes costata & mango? & fruit & 7 & 3 \\
\hline kemedu & & vine & cordage & & 3 \\
\hline kemunte' & & & fruit & & 1 \\
\hline kemunting & Melastoma spp. & & fruit & & 1 \\
\hline kepayang & Pangium edule/Scaphium spp. & & fruit & 2 & 1 \\
\hline kerupok & Pandanus spp. & pandanus & weaving & & 3 \\
\hline kubal & Sapotaceae/Apocynaceae & wild rubber & latex & & 2 \\
\hline kumpang & Myristaceae spp. & & fruit & & 4 \\
\hline laleh & Eugeissona spp. & palm & cabbage & & 2 \\
\hline lelanggai & Shorea spp. & & lumber & 1 & 5 \\
\hline lelekat & & & fruit & 2 & \\
\hline lema' adau & Baccaurea macrocarpa & & fruit & 1 & \\
\hline lensat & Lansium domesticum & & fruit & 11 & 3 \\
\hline limau & Citrus spp. & & fruit & 2 & \\
\hline lueh & Hopea spp. & & lumber & & 1 \\
\hline mawang & Mangifera kemanga/M. caesia & mango & fruit & 10 & 5 \\
\hline medang pawas & Lauraceae spp. & & lumber & 1 & \\
\hline
\end{tabular}


Table 2. Iban Plant Resources found in Specially Preserved Forest (continued)

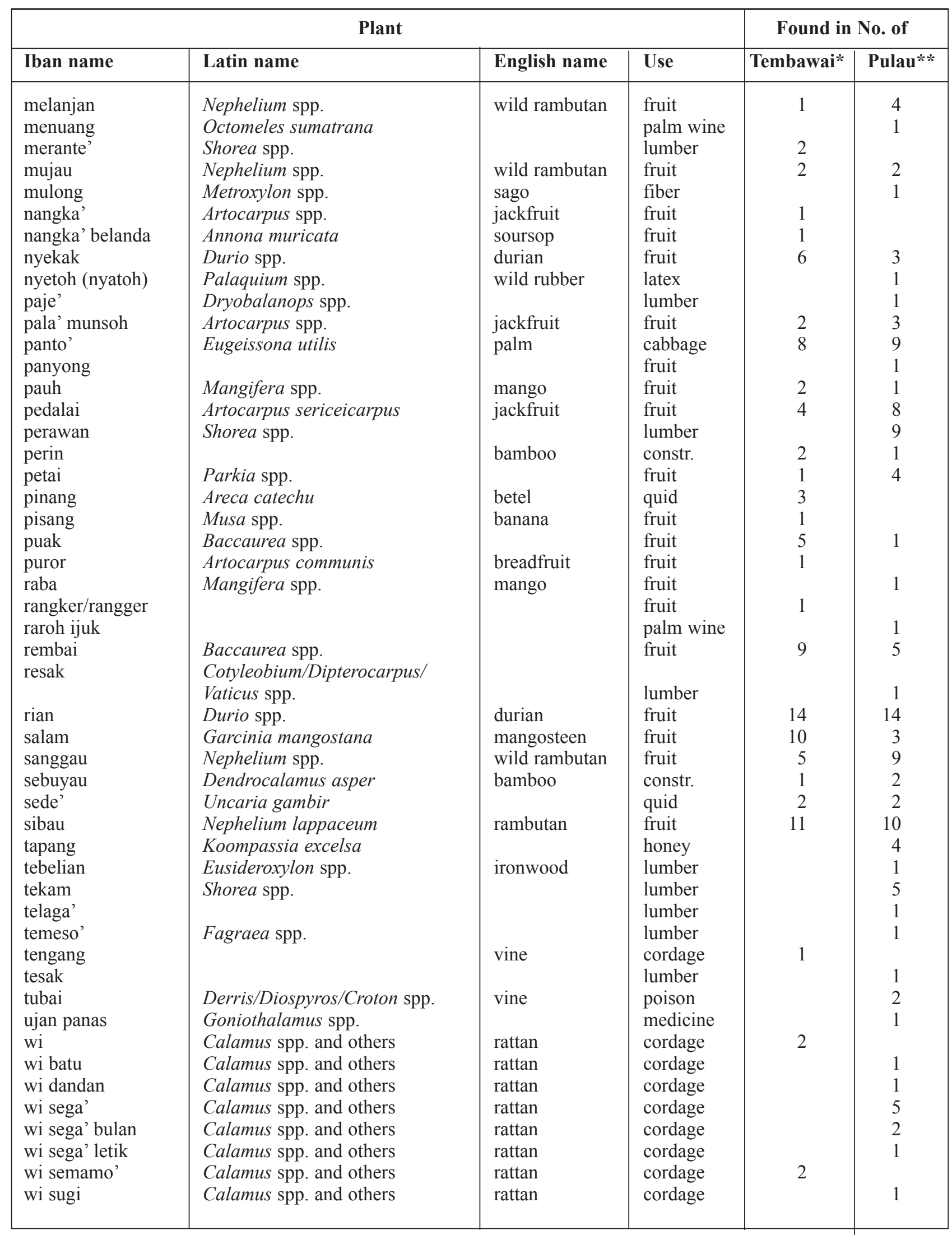

* 26 sites surveyed

** 46 sites surveyed 


\section{Box 1: \\ Iban Management - An Example}

Table 2 provides interesting information on the contrast between plants reportedly found in two forested indigenous land use types: tembawai (old longhouse sites) and pulau (specially preserved forest areas). Although both categories of sites show similar counts having fruit trees (domesticated, semi-domesticated and wild), eleven pulau have trees used for lumber in comparison to only three tembawai. Sixty-five per cent of the tembawai contain useful fruit trees compared to only 46.8 per cent of pulau. This illustrates the different nature of management for these two categories. Tembawai, even those that are over 100 years old, contain many fruit trees because while occupying a longhouse people plant fruit nearby. After abandonment of a longhouse, they promote the succession of saplings from the original trees, thus producing a forest patch dominated by fruit trees. Pulau, in contrast, are patches of forest that have been preserved from felling for various reasons - as sacred sites, as places to collect rattan or wild latex, and as places to cut lumber for longhouse construction. The succession of useful tree species is also promoted in these sites (see e.g., Sather 1990; Padoch and Peters 1993; Wadley et al. 1996).

For the other communities studied during this pretest, we had access to satellite imagery and the cooperation of a remote-sensing specialist (see Dennis et al. n.d.). This kind of information is important because we expect to compare our results from DSWR with those from similar tests in other locations. We will want to be able to demonstrate the condition of the for- est, as related to human well-being within and around that forest. Using Dennis' maps, we were able to provide fairly believable evidence that little or no dramatic forest loss had occurred in the three study villages.

For Wong Garai, in the absence of such a means for assessing the biological sustainability of the local situation, we used an indirect method based on farming

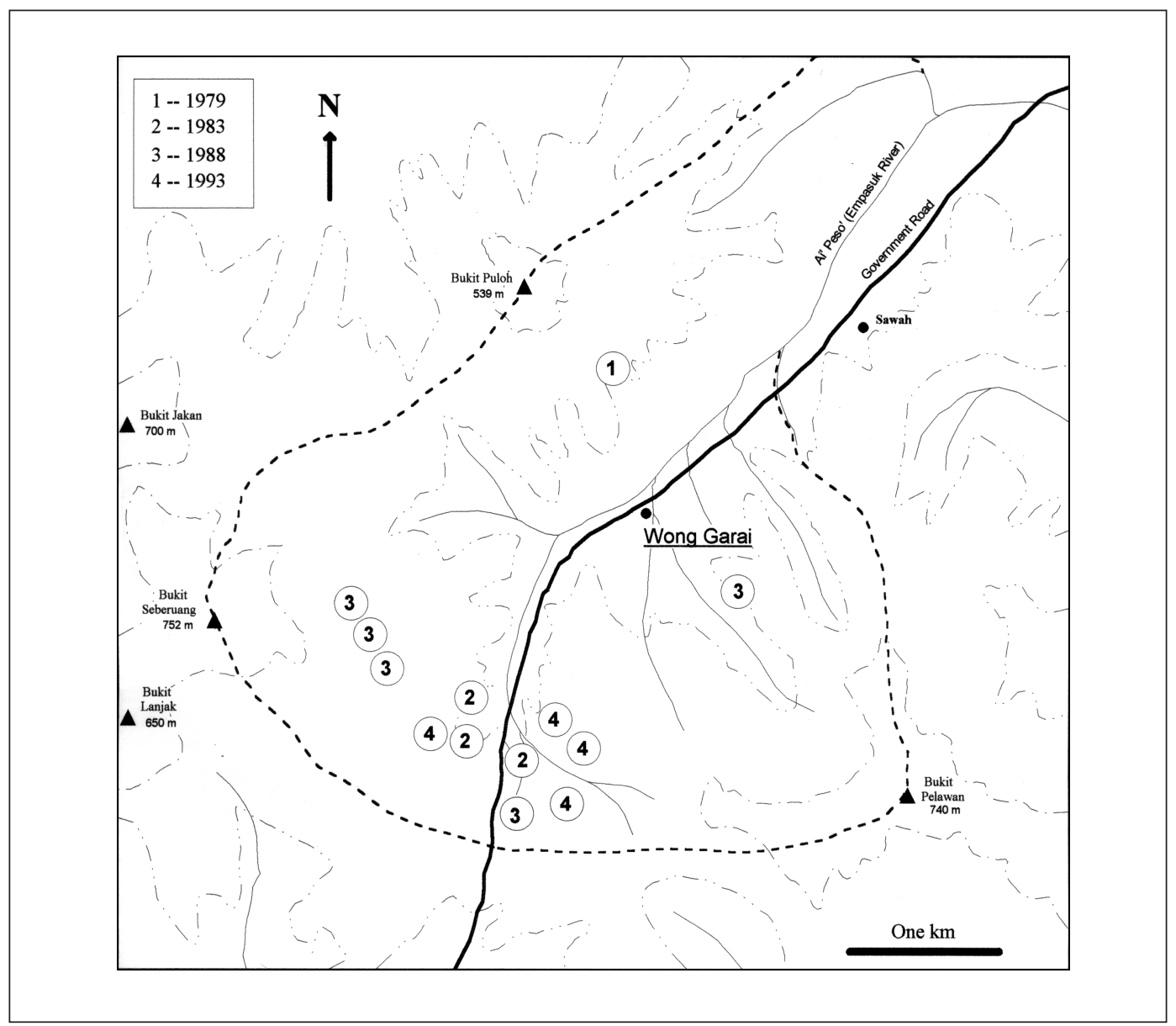

Figure 6. Location of Hill Swiddens, Wong Garai 
Table 3. Forest Type, Field Size and Fallow Length of Hill Swiddens, Wong Garai

\begin{tabular}{|c|c|c|c|c|c|}
\hline \multirow[b]{2}{*}{ Forest Type } & & \multicolumn{4}{|c|}{ Year } \\
\hline & & \multirow{2}{*}{$\frac{1979}{6}$} & \multirow{2}{*}{$\frac{1983}{4}$} & \multirow{2}{*}{$\frac{1988}{5}$} & 1993 \\
\hline Young & No. Fields & & & & 0 \\
\hline \multirow[t]{2}{*}{ Fallow } & & 19.28 & 14.77 & 15.39 & 0 \\
\hline & Ave. Fallow* & 7 & 5.25 & 8.6 & 0 \\
\hline \multirow{3}{*}{$\begin{array}{l}\text { Young } \\
\text { Secondary }\end{array}$} & No. Fields & 1 & 2 & 6 & 10 \\
\hline & & 2.87 & 9.45 & 16 & 32.79 \\
\hline & Ave. Fallow* & 30 & 13.5 & 19 & 20.8 \\
\hline \multirow{3}{*}{$\begin{array}{l}\text { Old } \\
\text { Secondary }\end{array}$} & No. Fields & 0 & 4 & 2 & 4 \\
\hline & & 0 & 20.53 & 11.09 & 14.41 \\
\hline & Ave. Fallow* & 0 & 45 & 39.5 & 38.75 \\
\hline \multirow[t]{3}{*}{ Total } & No. Fields & 7 & 10 & 13 & 14 \\
\hline & & 22.15 & 44.75 & 42.48 & 47.2 \\
\hline & Ave. Fallow* & 10.3 & 22.8 & 18.2 & 25.9 \\
\hline
\end{tabular}

* Average length of fallow is measured in years.

information collected during Wadley's initial research. Four years of farming data were selected $(1979,1983$, 1988 and 1993) that would give some indication of forest types being farmed, field sizes and the length of fallow used - all practices which have implications for forest cover. The locations of fields is given in Figure 6 with summary information in Table 3. This shows the increase in longhouse size from seven households in 1979 to 14 in 1993. As the number of households increased, so did the number of fields for each year surveyed; but there is no directly linear increase in the total area farmed by the whole community, although there is a rough increase. There does not appear to be, however, any decline in fallow length indicating land shortage or any increase in fallow length indicating the opening of old growth forest. What these data reveal is the annual cycling of fallowed forest - in some years young fallow, in other years older fallow - with an average fallow length overall of 22.7 years. Thus, these data suggest that forest cover, as with the other communities where satellite data were available, has remained fairly stable over the years. A subsequent and more detailed analysis of the Wong Garai situation supports these findings (Wadley n.d.).

The participatory mapping method was also of mixed value. Although it was useful in helping to capture human use of the forests, it did not produce results that would be easy for someone young, inexperienced and/or untrained to interpret, from the standpoint of sustainability. Assessors, as with the previous method, served as record keepers and analysts, but we sensed that our results were significantly enhanced by the fact that we were also able to serve as sensors or tools. The pertinence of our questions, as we accompanied community members, significantly influenced the quality of the responses - and our ability to ask pertinent questions was significantly influenced by our experience. The method, as implemented, contributed to our collection of case material for better understanding of the causal links between inter-generational access to resources and sustainable forest management.

Locally recruited team members (as representatives of the young, inexperienced and/or untrained) helped us by explaining things that were not clear to us, based on their own intimate knowledge of the area, combined with their fluency in the local language. But for best results, assessors will probably require either considerable experience or training. We hope that the scoring technique suggested in the next section may help address this problem.

\section{“Iterative Continuum Method” (ICM)}

This experimental, qualitative method was designed to provide a framework within which to organise one's thoughts and emerging understanding of site conditions, over the course of necessarily brief fieldwork. The form used with this method is also simple. We devised sheets, for use by the field team on a daily basis, with a continuum at the top of each, and space below for notes (Appendix A). Researchers filled in one form on each day of the fieldwork, assessing where the community (or sub-groups within the community) should be placed along the continuum, based on the researcher's understanding, as of that day. ${ }^{18}$ Placement was accompanied by an arrow to show the researcher's perception of the direction of change. The spaces on the pages were then filled with evidence to support the conclusions marked on the continuum. An attempt to estimate the speed of change was shown by colour-coding the arrows. The process of filling in these forms was iterative, in which the researchers'

18 This combines some of the approaches suggested by Pretty (1994), e.g., persistent and critical observation, negative case analysis and reflexive journals. 


\section{Box 2: \\ Filling in the ICM - An Example}

When Colfer began the 1996 pre-test, she was uncertain about people's feelings of security about their tenure and use rights in the area. She remembered her first visit there in 1992, when a group of villagers had explained that they had no rights to the land on Bukit Kedebu', that they were "really" residents of Selimbau, a larger town on the Kapuas river. Based on this assertion, she and her husband had proceeded with their plan to build the DSWR Field Center there. Much to their surprise, the local governmental triad (police, military and district government) called a meeting at which a man from yet another village asserted most aggressively that he and 14 other people "owned" Bukit Kedebu'. Although this disagreement was resolved eventually to everyone's apparent satisfaction, Colfer concluded over the next 15 months that there was a very confusing mélange of ownership and use rights in the area.

How could she better understand the importance of such use rights to sustainable forest management? One important issue identified in the literature seemed to be the presence and operation of regulations. She began looking for further evidence of regulations. She knew they existed in fisheries, but what about forests? She found evidence that the Melayu considered rattan harvesting to be subject to regulation by local communities, and that permission had to be given before one could harvest it. She found regulations among the Iban about collection of forest foods. Did these seem to be regularly applied? Were there sanctions? One question led to another, always keeping in mind the link to the state of the forests in the area and the likelihood and direction of change.

Mechanisms for conflict resolution represented another feature that previous CIFOR research (and the literature) had identified as important for SFM. The potentially bad effects of conflict on forests also became clear in the course of the fieldwork. She began listening for stories of conflicts and trying to understand how people resolved them. There were conflicts between timber companies and local communities, some of which were resolved by negotiation, others by violence. There were conflicts between neighbouring communities over appropriate fishing gear, boundaries and regulations. The various methods of resolution were duly noted.

The ICM process requires the researcher to keep alert and to be open to many kinds of evidence - because of the huge variety in human uses of forests. One observation leads to others, following the connections among human values and behaviour, on the one hand, and sustainable forest management, on the other. Experience in participant observation techniques is also helpful in this process.

growing understanding is reflected in changes in daily assessments. Care was taken to assess the amount of time spent on this activity each day, as a means of assessing its cost effectiveness.

To gain the kind of understanding needed to estimate the placement of a community or sub-group along the continuum, we spent days with representatives of the various stakeholders and sub-groups, discussing, observing, inquiring, using elements from Vayda's contextual analysis approach (Vayda et al. 1980; Vayda 1983). This approach strives to trace the links among significant human actions - such as felling timber, monitoring concessionaires or contributing ideas about forest management to conservation project personnel - in the research setting. The emphasis in this research was on tracing causal links, ${ }^{19}$ to demonstrate the relevance (or irrelevance) of particular kinds of human actions for sustainable forest management.
The researcher filled in the form, supporting the initial assessment with cases and evidence. During the process of reassessing the data and filling out the forms subsequently, additional cases and evidence to account for the changes in the researchers' perceptions were documented. The reasoning was that by the end of the fieldwork, the state and direction of change along the continua for the locations studied would thereby be fine-tuned, and the factors affecting forest management better understood.

As a further check on our emerging understanding, we asked several other stakeholders (traders, intellectually oriented villagers, inhabitants of the larger, linked towns on the Kapuas) to fill in these forms, as the opportunity arose. We reasoned that these people would have a much deeper familiarity with local conditions than ourselves, so we did not ask them to keep a daily record. Besides giving us another perspective on the substantive issues we were investigating, this

19 See Vayda (1996) for an interesting, philosophical discussion of methods of study and relationships among human actions and their environmental effects. 
procedure was designed to give us some feedback on how simple or difficult the method was for others with less social science training than we have.

Our attempt to have local people and our assistants use the ICM form was not particularly useful. The primary reason was that they did not have the global perspective necessary to place themselves on a continuum (other than perhaps one pertaining to their own trajectory toward or away from sustainability). ${ }^{20}$ Indeed, Wadley and Colfer had similar problems with the method, feeling the need for some defined points along the continuum (from secure to insecure access to resources) to help us "anchor" our observations from day to day. In response to this problem, Colfer began a tentative series of steps from "very insecure tenure" to "very secure tenure" which are shown in Appendix B. These steps were helpful in making her daily entries, and would be even more helpful if refined, for use by less educated (but trained) assessors. Our general view was that the people in the DSWR area fit around 4 or 5 on a 10-point scale, as tentatively presented in Appendix B. The utility of this scale however will be greatly improved with the inclusion of similar assessments from sites in other areas of the world.

Our evaluation of this method, like the previous ones, is mixed. On the one hand, it kept us focused on the issue of security of inter-generational access to the resource, recording what we learned, and thinking about the implications thereof. It also resulted in a wealth of case material relating to the topic of interest. On the other hand, we are not confident of the ability of less experienced researchers, less familiar with the context, to use the method as reliably. This method requires assessors to record and analyse data, and also to act as sensors or tools - as anthropologists normally do, but for which a typical assessor would need special training.

In response to our dissatisfaction with these methods, and based on our analysis of the case materials (see next section), we have re-organised the principles, criteria and indicators, so as to help us in scoring them, based on the rich case materials we collected.

\section{Methodological Conclusions}

We remain dissatisfied with the methods available for assessing inter-generational access to resources. Although all of these methods were useful and none was discarded, our search for better methods contin- ues. ${ }^{21}$ The history form is fairly easy but not sufficiently informative; the mapping exercise provides qualitative information that will be better collected and interpreted the higher the qualifications and experience of the assessor; and the ICM requires even more global experience and sophistication in its current form. We do however feel that overall we have been able to make both conceptual and methodological progress in the process of assessment (see next section).

\section{PRINCIPLES, CRITERIA AND INDICATORS FOR ASSESSING INTER-GENERATIONAL ACCESS TO RESOURCES}

The goal of developing clear and relevant principles, criteria and indicators for assessing sustainable forest management has been hotly pursued in recent years (see Upton and Bass 1995 for a good overview). No element in this process has been more controversial, or more difficult to attain, than the development of good social C\&I. We have entered this process in full recognition of its difficulty and with some uncertainty about the possibility of success. But the potential gains:

- the existence of simple assessment tools,

- the potential of influencing forest managers to attend meaningfully to resident communities (in all their variety),

- a greater share of the forest "pie" and a greater "voice" for those currently disadvantaged,

- improved understanding of the causal links between human behaviour/beliefs and SFM, and

- improved management of resources through better information

should we (globally) succeed, make it worth the gamble. We do, however, still have a long way to go.

\section{History}

We first provide a brief history of our own involvement in this process, including earlier iterations of social C\&I, to provide a context. These efforts are part of an overall attempt to develop C\&I for SFM, including

20 Sue Ellen Johnson, one of our collaborators in Cameroon, has designed an ICM study which will do just that (pers. comm. 4 February 1997).

21 CIFOR teams and collaborators are now testing several additional methods in Cameroon and East Kalimantan: historical trend analysis (Participatory Rural Appraisal Handbook 1990); transects of landscape: past, present and projected (adapted from Poffenberger and McGean 1993b); benefit sharing among stakeholders: pebble distribution method 1; and access to resources by generation: pebble distribution method 2; as well as those reported above. 
Table 4. Principles, Criteria and Indicators Selected by all CIFOR Field Assessment Teams

\title{
P: Forest management maintains fair inter-generational access to resources and economic benefits.
}

C: Stakeholders/forest actors' tenure and use rights are secure.

- I: Tenure/use rights are well defined and upheld.

- I: Opportunities exist for local people/forest-dependent people to get employment and training from forest companies.

- I: Forest-dependent people share in economic benefits of forest utilisation.

\section{P: Stakeholders, including forest actors, have a voice in forest management.}

\author{
C: Stakeholders/local populations participate in forest management \\ - I: Effective mechanisms exist for two way communication related to forest management \\ among stakeholders. \\ - I: Forest-dependent people and company officials understand each other's plans and \\ interests.

\section{C: Forest-dependent people/stakeholders have the right to help monitor forest utilisation} \\ - I: Conflicts are minimal or settled.
}

social, ecological and conventional management considerations (e.g., Prabhu et al. 1996). Naturally there is overlap in concerns among these areas, some of which will become clearer below.

Within the social sphere, we first developed a conceptual framework from which to approach C\&I (Colfer et al. 1995). This was done, as has much of our work, using oscillating iterations of top-down, bottomup, conceptual cycling. We looked first at existing C\&I (e.g., ITTO 1992; Rainforest Alliance 1993; Forest Stewardship Council 1994; Lembaga Ekolabel Indonesia 1994; Soil Association 1994), and then we developed C\&I based on our own experience with forest people. We then compared this first draft of fieldbased C\&I with those from the existing sets; and revised yet again (see Colfer et al. 1995).

We subsequently assembled a number of interdisciplinary teams who tested sets of C\&I in and around various logging concessions (in Indonesia, Côte d'Ivoire, Brazil, Austria, Cameroon). ${ }^{22}$ On analysis of their results, we found a number of C\&I that were common to all the sets (Prabhu et al. 1996: 50). In Table 4, we list the common social C\&I.

These principles, criteria and indicators are, of course, taken out of context, so they do not provide the coherence that will ultimately be desirable - either within the sphere of social C\&I alone, or as part of a comprehensive set of policy, ecological and conventional forest management C\&I. But they do identify some of the important issues that we have addressed in this research. Indeed, the above results led to the research reported here.

Table 5 shows our current conceptual framework for issues pertaining to inter-generational access to resources. ${ }^{23}$ This revision has resulted from our previous experience, particularly our West Kalimantan pretest of methods. Although dissatisfied with our methodological progress on this topic during the pretest, we made modest progress toward answering the question posed at the beginning of this article: Why, and by what means, is inter-generational access to resources important for sustainable forest management? In the subsequent pages, we try to make these links clearer by means of cases from the DSWR area. Our hope is that these cases can spur other researchers to add to our growing fund of case materials pertaining to this topic. We also suggest a simple scoring technique. We hope that, if our attempt to develop more quantifiable methods fails, we will have made some progress in outlining the relevant qualitative features.

22 Each team produced a report: Burgess et al. 1995 for Indonesia; Mengin-Lecreulx et al. 1995 for Côte d'Ivoire; Zweede et al. 1996 for Brazil; Federal Ministry of Environment, Youth and Family 1996 for Austria; and Prabhu and Colfer 1996 for Cameroon.

23 We felt comfortable following Lammerts van Bueren and Blom's (1997) requirements for "principles" and "criteria"; but the indicators we have developed combine their "indicators" and "norms" and are, in the case of this principle, almost exclusively qualitative. 
Table 5. Proposed Principles, Criteria and Indicators Pertaining to Security of Inter-generational Access to Resources

(P) Forest management maintains fair inter-generational access to resources and economic benefits

(C)1. Local management is effective in controlling maintenance of and access to the resource.

1.1 ownership and use rights to resources (inter and intra generational) are clear and respect pre-existing claims

1.2 rules and norms of resource use are monitored and enforced

1.3 means of conflict resolution function without violence

1.4 access to forest resources is perceived locally to be fair

1.5 local people feel secure about access to resources

(C)2. Forest actors have a reasonable share in the economic benefits derived from forest use.

2.1 Opportunities exist for local and forest dependent people to get employment and training from forest companies

2.2 Damages are compensated in a fair manner

2.3 Wages and other benefits conform to national and/or ILO standards

2.4 Fair mechanisms exist for sharing benefits with local communities.

(C)3 People link their and their children's future with management of forest resources.

3.1 People invest in their surroundings (e.g., time, effort, money)

3.2 Out-migration levels are $10 \mathrm{w}^{24}$

3.3 People recognise the need to balance numbers of people with natural resource use

3.4 Children are educated (formally and informally) about natural resource management

3.5 Destruction of natural resources by local communities is rare.

3.6 People maintain spiritual links to the land.

\section{Commentary}

One prerequisite for achieving inter-generational access to forest resources by forest people is the maintenance of the forest resources. That is, if the forests and their resources have been depleted or destroyed, it is impossible for the current or next generation to have access to them. This concern results in the first criterion (C1) in Table 5 and its indicators, the development of which has been influenced by Ostrom's work (1990, 1994; Wollenberg and Colfer 1996). Clearly there is a host of complementary ecological C\&I that we ignore here.

There is overlap between the C\&I discussed here and other social C\&I. For instance, Indicator C1.1 ("ownership and use rights to resources...are clear and respect pre-existing claims") has implications for the question of voice in forest management or co-management. Without a firm economic base, forest actors may remain comparatively silent and powerless (see
Gatuslao 1988 and Canuday 1996, for some recent counter examples).

The distinction between criteria C1 ("Local management is effective in controlling maintenance of and access to the resource.") and C2 ("Forest actors have a reasonable share in the economic benefits derived from forest use.") has been confusing to some biological scientists. It may help to think in terms of input and output variables, with $\mathrm{C} 1$ as an input (the basis on which access to resources rests) and $\mathrm{C} 2$ as an output (the products that come from that resource base).

Finally, our work has been influenced by a perhaps unwarranted assumption that C\&I can be organised into hierarchies. Considerable progress has been made in improving our definitions of principles, criteria, indicators and verifiers (see Prabhu 1995 or Lammerts van Bueren and Blom 1997); but we remain uncertain whether these hierarchical connections are as immutable as they may seem on paper. An indicator in one context can, in our view, function as a criterion in

24 C3.2 and C3.3 contain a potential contradiction. Low levels of out-migration (C3.2) indicate that people link their and their children's future to maintaining the forest; yet recognising the need to balance numbers of people with natural resource use (C3.3) may lead them to favour out-migration. This contradiction would likely occur when conditions are deteriorating. 
another; and vice versa. Income levels, for instance, may be considered (and phrased as) an indicator for a criterion on the state of people's health; or conversely, adequate incomes could be conceived as a criterion for human well-being, with human health as an indicator. The hierarchical approach has its appeal, but we wonder also if, as Young (1992: 144) implies, there may be more hierarchical levels which need to be applied for social phenomena. He quotes Thoreau (1854: 197), who says "the imagination, give it the least license, dives deeper and soars higher than Nature does". Is it possible that human systems, more directly affected by human imagination, may require more levels than we are allowing in Lammerts van Bueren and Blom's interesting formulation? Or must we ultimately recognise a certain arbitrariness in our hierarchies? These are not questions we can answer in this short paper. We do, however, view the use of the hierarchical formulation as a means rather than an end. It has utility insofar as it can further our understanding of these problems. We are currently considering looking at these issues from a network perspective.

\section{Cases from DSWR Pertaining to Inter-generational Access to Resources}

Appendix C portrays the examples or cases that contributed to our qualitative assessment of "security of inter-generational access to resources" in and around DSWR. Examining previous C\&I, along with the cases found in DSWR, we revised the C\&I. In an attempt to quantify the qualitative, each author made a comparatively independent assessment of these cases (Table 6). ${ }^{25}$ For each criterion or indicator, ${ }^{26}$ a score qualitatively determined - between 1 and 10 is provided, with 10 representing the most sustainable value. The "Tentative Steps to Sustainability - Security of Inter-generational access to Resources" (Appendix B) provided a conceptual anchoring function, but the scoring process was primarily one of personal judgement, based on the kinds of evidence presented under each indicator. The final column provides the average scores for each C\&I. We were pleasantly surprised at the similarity of our scores. Hopefully repeated use of this method can provide us with more cases and a clearer basis on which to make these judgements.
The fact that the forests in and around DSWR are in comparatively good condition suggests that these scores may be high, on a global scale. The low average score (2.5) for Criterion 2 ("Forest actors have a reasonable share in the economic benefits derived from forest use.") suggests a possible flash point; and indeed feelings of unfairness about local people's share in forest benefits that they felt should be their own, were both a recurring complaint and a rationale for examples of violent confrontation. ${ }^{27}$ Our comparatively high assessments of the strength of their feelings of security about access to resources (7) and their clear conceptual link between their own and their children's well-being and the forests (5.4) seem likely to contribute to sustainability by a) confirming their "stake" in the forest, and b) providing motivation for protecting it against potentially destructive new endeavours in the area.

A further and important test of the utility of this approach will come when we can compare these kinds of findings with our results in Cameroon, East Kalimantan and Brazil, where we are using the same methods (with additional ones).

\section{IN CONCLUSION}

This paper has evaluated our experience with several methods designed to assess inter-generational access to resources quickly, inexpensively and reliably. In this endeavour we have also developed another iteration of principles, criteria and indicators, with supporting evidence and a proposed scoring technique. The extensive evidence which led to our reformulation of the principles, criteria and indicators (Appendix C) can be evaluated by other assessors for potential use in other locales. We see such case material as the beginning of a "library" of cases from different contexts, building ultimately to a fuller understanding of the causal links between security of inter-generational access to resources and sustainable forest management.

We continue to hope that better methods - ones that are more quantitative, more transparent, requiring less expertise and experience - will emerge in our (and others') further testing of methods. But we are pleased that all three authors were inclined to score the rather extensive, qualitative case material in a fairly consistent manner.

25 Wadley and Harwell saw Colfer's preliminary scoring; but each tried to ignore Colfer's scores and record his/her views independently

26 Colfer and Wadley are in communication by e-mail, but Harwell remains in the field. Our communication problems resulted in her assessing only the criteria.

27 In early 1997, in another area of West Kalimantan, a confrontation occurred, so violent that large numbers of people were killed and the military intervened. Although its causes are widely debated (often attributed to ethnic or religious conflict), we feel some confidence that inequitable access to resources and benefits played a significant role in this sad occurrence. 
Table 6. Scoring of C\&I by Colfer, Wadley and Harwell

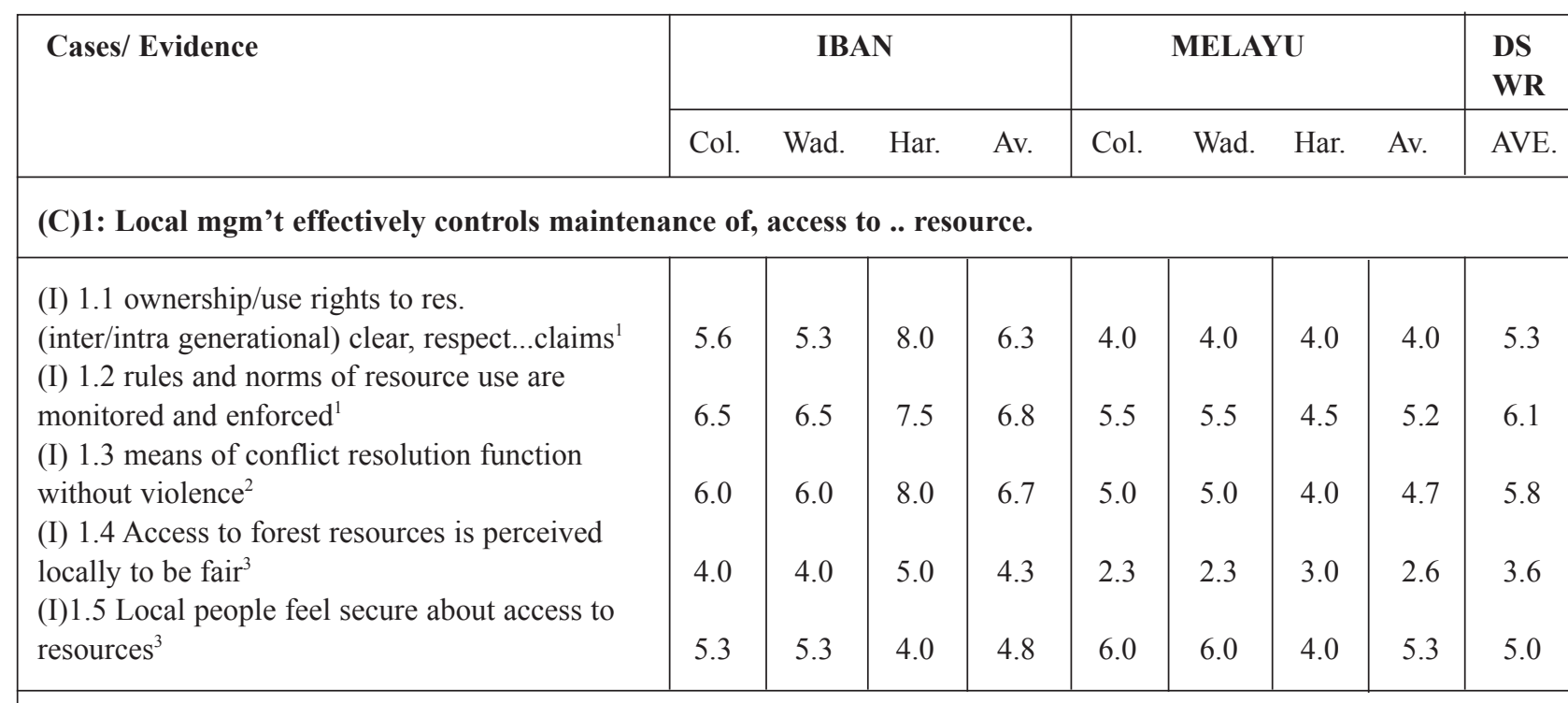

(C)2: Forest actors have reason. share in the econ. benefits..from forest use.

(I) 2.1 Local people get employment and training from forest companies

(I) 2.2 Damages are compensated in a fair manner ${ }^{5}$

(I) 2.3 Wages and other benefits conform to national and/or ILO standards ${ }^{6}$

(I) 2.4 Fair mechanisms exist for sharing benefits with local communities ${ }^{4}$

\begin{tabular}{|l|l|l|}
3.0 & 3.0 & 2.0 \\
3.5 & 3.5 & 3.0 \\
2.0 & 2.0 & 3.0 \\
4.0 & 4.0 & 2.0
\end{tabular}

\begin{tabular}{|l|l|l|l|l|l|}
2.7 & 2.0 & 2.0 & 2.0 & 2.0 & 2.4 \\
3.3 & & & 3.0 & 3.0 & 3.3 \\
2.3 & & & 3.0 & 3.0 & 2.5 \\
3.3 & 2.7 & 2.7 & 2.0 & 2.4 & 3.0 \\
\hline
\end{tabular}

\section{(C)3: People link their/ their children's future with mgm't of forest resources.}

(I) 3.1 People invest in their surroundings (time, effort, money, etc.) ${ }^{4}$

(I) 3.2 People recognise need to balance no. people with natural resources ${ }^{2}$

(I) 3.3 Children educated (formally and/or informally) about nat. res. mgm't ${ }^{4}$

(I) 3.4 Destruction of natural resources by local communities is rare. ${ }^{4}$

(I) 3.6 People maintain spiritual links to the land ${ }^{3}$

\section{GRAND MEAN}

\begin{tabular}{|l|c|c|c|c|c|c|c|c|}
8.0 & 8.0 & 8.0 & 8.0 & 8.0 & 8.7 & 4.0 & 6.9 & 7.5 \\
6.3 & 6.3 & 7.0 & 6.6 & 5.0 & 5.0 & 2.5 & 4.2 & 5.5 \\
5.7 & 6.0 & 4.0 & 5.2 & & & 4.0 & 4.0 & 5.0 \\
4.0 & 4.0 & 5.0 & 4.3 & 4.0 & 4.0 & 5.0 & 4.3 & 4.3 \\
8.7 & 8.7 & 9.0 & 8.8 & 5.0 & 5.0 & 3.0 & 4.3 & 6.9 \\
\hline
\end{tabular}

Notes:

1 Based on average scores (Colfer, Wadley) for 6 cases (see Appendix C)

2 Based on average scores (Colfer, Wadley) for 5 cases (see Appendix C)

3 Based on average scores (Colfer, Wadley) for 4 cases (see Appendix C)

4 Based on average scores (Colfer, Wadley) for 3 cases (see Appendix C)

5 Based on average scores (Colfer, Wadley) for 2 cases (see Appendix C)

6 Based on average scores (Colfer, Wadley) for 1 case (see Appendix C) 
Our attempt to understand the causal links between inter-generational access to resources and sustainable forest management is a long term goal. But our revised organisation and wording of the C\&I on this topic reflect our improved understanding. We cannot say, of course, based on our limited field experience to date, that maintenance of fair inter-generational access to resources and economic benefits is always important for sustainable forest management. The evidence, or cases, we accumulated for DSWR, however (like that of many other researchers), tend to support this inter- pretation and do not provide counter-evidence. Based on our examination of security of inter-generational access to resources there, we concluded that "best practices" in forest management - whether by local people or by timber concessionaires - will require a) that resources be maintained if people now and in the future are to continue to have access to them $(\mathrm{C} 1) ; \mathrm{b}$ ) that local people must share in the economic benefits from forest use (C2); and c) that people (in this case, also managers $)^{28}$ must link their own and their children's future with good management of the resource.

28 The role local people play in management in and around DSWR is examined in Colfer and Wadley (1996). 


\section{Bibliography}

Ascher, W. 1993. Political economy and problematic forestry policies in Indonesia: obstacles to incorporating sound economics and science. Center for Tropical Conservation, Duke University, Durham, North Carolina.

Becker, B. 1997. Sustainability Assessment: A Review of Values, Concepts and Methodological Approaches. Consultative Group on International Agricultural Research, Washington, DC.

Bernstein, J.H., R. Ellen and Bantong Antaran. n.d. The use of plot surveys for the study of ethnobotanical knowledge: a Brunei Dusun example. Unpublished manuscript.

Besley, T. 1995. Property rights and investment incentives: theory and evidence from Ghana. Journal of Political Economy 103: 903-937.

Bruce, J.W. 1989. Community Forestry: Rapid Appraisal of Tree and Land Tenure. FAO, Rome.

Burgess, P. 1995. Final report: test Indonesia, March 5 - April 2, P.T. Kiani Lestari Jaya. (C.J. Pierce Colfer and R. Prabhu, eds) CIFOR Project document, Bogor, Indonesia.

Canuday, J.F. 1996. Fight vs. mining, logging: Lumads ready for total war. Philippine Daily Inquirer 8 October, page 17.

Carter, J. 1996. Recent Approaches to Participatory Forest Resource Assessment. Rural Development Forestry Study Guide 2. ODI, London.

Chatterji, A.P. with A. Schwarz and Arabari Communities. 1996. Community Forest Management in Arabari: Understanding Sociocultural and Subsistence issues. Society for Promotion of Wastelands Development, New Delhi.

Christiansen, H. n.d. Iban plant classification and plant names. Unpublished manuscript.

Colfer, C.J. Pierce. 1995. Who Counts Most in Sustainable Forest Management? CIFOR Working Paper No. 7. Bogor, Indonesia.

Colfer, C.J. Pierce and R.L. Wadley. 1996. Assessing "Participation" in Forest Management: Workable Methods and Unworkable Assumptions. CIFOR Working Paper No. 12. Bogor, Indonesia.

Colfer, C.J. Pierce with N. Peluso and Chin See Chung. 1997. Beyond Slash and Burn: Lessons from the Kenyah on Managing Borneo's Rain Forests. New York Botanical Garden, New York. in press.

Colfer, C.J. Pierce with R. Prabhu and E. Wollenberg. 1995. Principles, Criteria and Indicators: Applying Ockham's Razor to the People-Forestry Link. CIFOR Working Paper No. 8. Bogor, Indonesia.

Colfer, C.J. Pierce, R.L. Wadley, Budi Suriansyah and Enis Widjanarti. 1993. Use of forest products in three communities: a preliminary view. In: R.G. Dudley and C.J. Pierce Colfer (eds), Conservation Sub-Project Quarterly Report and Attachments. Asian Wetland Bureau (now Wetlands International), Bogor. Study Number 7.

Colfer, C.J. Pierce, J. Woelfel, R.L. Wadley and E. Harwell. 1996. Assessing People's Perceptions of Forests in Danau Sentarum Wildlife Reserve. CIFOR Working Paper No. 13. Bogor, Indonesia.

Dennis, R.A. and E. Erman 1997. Community-level Mapping in and around the Danau Sentarum Wildlife Reserve, West Kalimantan. DfID-Indonesian Tropical Forestry Management Project Report. Jakarta.

Dennis, R.A., C.J. Pierce Colfer and A. Puntodewo. n.d. Assessing the Biophysical Aspects of Sustainable Forest Management Using Remote Sensing: An Indonesian Example. CIFOR C\&I Project/DfID Indonesian Tropical Forestry Management Project, Conservation Sub-Project draft. Jakarta.

Dudley, R.G. 1996a. The Fishery of the Danau Sentarum Wildlife Reserve, West Kalimantan, Indonesia: Fishery Analysis. Report to Wetlands International, Bogor, Indonesia.

Dudley, R.G. 1996b. The Fishery of the Danau Sentarum Wildlife Reserve, West Kalimantan, Indonesia: Management Considerations. Report to Wetlands International, Bogor, Indonesia.

Farmer, A. and J. Tiefenthaler. 1995. Fairness concepts and the intrahousehold allocation of resources. Journal of Development Economics 47: 179-189.

Federal Ministry of Environment, Youth and Family. 1996. Testing of Criteria and Indicators of Sustainable Forest 
Management within the International CIFOR Project (special edition). Vienna, Austria.

Forest Stewardship Council. 1994. Forest Stewardship Council Ratification Documents (July). Oaxaca, Mexico.

Fortmann, L. and J.W. Bruce. (eds). 1988. Whose Trees? Proprietary Dimensions of Forestry. Westview Press, Boulder, Colorado.

Gatuslao, R.M. 1988. The Higaonons’ War. Midweek 21 December, pp. 3-5.

Giesen, W. 1987. Danau Sentarum Wildlife Reserve: Inventory, Ecology and Management Guidelines. WWF and PHPA, Bogor, Indonesia.

Grigsby, W. 1995. The Nature of Land: Tenure in an Uncertain Environment. Doctoral dissertation, Washington State University.

ITTO. 1992. Criteria for the Measurement of Sustainable Tropical Forest Management. International Tropical Timber Organization, Yokohama.

Lammerts van Bueren, E.M. and E. Blom. 1997. Hierarchical Framework for the Formulation of Sustainable Forest Management Standards: Principles, Criteria and Indicators. The Tropenbos Foundation, Leiden.

Lembaga Ekolabel Indonesia. 1994. Criteria, variables and indicators of sustainable forest management for determining Indonesian ecolabel. Paper presented at International Conference on Forest Production Certification System: A Case Study of Indonesian Scheme. 14-16 September, Indonesia, Pacet-Puncak.

Lightfoot, C., S. Feldman and M. Zainul Abedin. 1991. Households, Agroecosystems and Rural Resources Management. ICLARM, Manila.

Lueck, D. 1995. Property rights and the economic logic of wildlife institutions. Natural Resources Journal 35: 625670 .

Lynch, O.J. and J.B. Alcorn. 1994. Tenurial rights and community-based conservation. In: D. Western and R. M. Wright (eds), Natural Connections: Perspectives in Community-based Conservation. Island Press, Washington, DC. pp. 373-392.

Mengin-Lecreulx, P. with A. Anvo, C. Huttel, H. van Haaften and N'Guessan K. Anatole. 1995. Final report: test Côte d'Ivoire, June 2-30 (translated by Guy Ferlin, edited by Ravi Prabhu and Lay-Cheng Tan). Bogor, Indonesia.

Momberg, F., K. Atok and M. Sirait. 1996. Drawing on Local Knowledge. A Community Mapping Training Manual: Case Studies from Indonesia. Ford Foundation, Yayasan Karya Sosial Pancur Kasih and WWF, Jakarta.

Nurse, M.C., C.R. McKay, J.T. Young and C.A. Asanga. 1995. Biodiversity conservation through community forestry, in the montane forests of Cameroon. Rural Development Forestry Network Paper 18d, ODI, Regent's College, Regent's Park, London. Winter 1994-Spring 1995: 14-19.

Ostrom, E. 1990. Governing the Commons: The Evolution of Institutions for Collective Action. Cambridge University Press, Cambridge.

Ostrom, E. 1994. Neither Market nor State: Governance of Common-pool Resources in the Twenty-first Century. International Food Policy Research Institute, Washington, DC.

Padoch, C. and C. Peters. 1993. Managed forest gardens in West Kalimantan, Indonesia. In: C.S. Potter, J.I. Cohen and D. Janczewski (eds), Perspectives on Biodiversity: Case Studies of Genetic Resource Conservation and Development AAAS Press, Washington, DC. pp. 167-176.

Pandey, D.N., S. Chadha, A. Chatterjee, A. Swarz and M. Poffenberger. 1997. Participatory Mapping for Joint Forest Management Inventory, Planning, and Monitoring: Methods Manual (Volume Three). Asia Forest Network, Berkeley and New Delhi.

Participatory Rural Appraisal Handbook. 1990. World Resources Institute, Natural Resources Management Support Series No. 1. Prepared jointly by National Environment Secretariat, Edgerton University, Clark University and the Center for International Development and Environment of the World Resources Institute. Washington, DC.

Peluso, N. 1994. The Impact of Social and Environmental Change on Forest Management: A Case Study from West Kalimantan, Indonesia. Community Forestry Case Study Series No. 8. FAO, Rome. 
Poffenberger, M. and B. McGean. (eds). 1993a. Upland Philippine Communities: Guardians of the Final Forest Frontiers. Asia Forest Network Research Network Report No. 4 (August). Centre for Southeast Asia Studies, Berkeley, California.

Poffenberger, M. and B. McGean. (eds). 1993b. Community Allies: Forest Co-Management in Thailand. Asia Forest Network Research Network Report No. 2 (August). Centre for Southeast Asia Studies, Berkeley, California.

Poffenberger, M. with P. Bhattacharya, A. Khare, A.Rai, S.B. Roy, N. Singh and K. Singh. 1996. Grassroots Forest Protection: East Indian Experiences. Asia Forest Network Research Network Report No. 7 (March). Centre for Southeast Asia Studies, Berkeley, California.

Poffenberger, M., C. Josayma, P. Walpole and K. Lawrence. 1995. Transitions in Forest Management: Shifting Community Forestry from Project to Process. Asia Forest Network Research Network Report No. 6 (August). Centre for Southeast Asia Studies, Berkeley, California.

Prabhu, R. 1995. A conceptual framework for a system to evaluate the sustainability of forest ecosystem management: a discussion paper. CIFOR internal document.

Prabhu, R. and C.J. Pierce Colfer. 1996. Interim Report on Cameroon Test. CIFOR Project Document. Bogor, Indonesia.

Prabhu, R., C.J. Pierce Colfer, P. Venkateswarlu, L.C.Tan, Rinekso Soekmadi and E. Wollenberg. 1996. Testing Criteria and Indicators for the Sustainable Management of Forests: Phase I Final Report. CIFOR Special Publication. Bogor, Indonesia.

Prabhu, R. and co-authors. 1997. CIFOR Report of Cameroon Test. Bogor, Indonesia. In preparation.

Prakash, S. and M. Thompson. 1994. Institutions and transactions: the risk and fairness approach to environmental economics. Proposal submitted to CIFOR (November).

Pretty, J.N. 1994. Alternative systems of inquiry for sustainable agriculture. IDS Bulletin 25(2): 37-48.

Rainforest Alliance. 1993. Smart Wood certification program: generic guidelines for assessing natural forest management (Revised Draft, October). New York.

Rose, C. 1994. Property and Persuasion: Essays on the History, Theory and Rhetoric of Ownership. Westview Press, Boulder, Colorado.

Sandin, B. 1980. Iban Adat and Augury. Universiti Sains Malaysia, Penang, Malaysia.

Sather, C. 1990. Trees and tree tenure in Paku Iban society: the management of secondary forest resources in a long-established Iban community. Borneo Review 1: 16-40.

Sirait, M., N. Podger, A. Flavelle and J. Fox. 1994. Mapping customary land in East Kalimantan, Indonesia: A tool for forest management. Ambio 23: 411-417.

Soil Association. 1994. Responsible forestry standards (February). United Kingdom.

Tainter, J.A. 1995. Sustainability of complex societies. Futures 27: 397-407.

Thoreau, H.D. 1854. Walden. (Reprinted 1957). Edited by S. Paul. The Riverside Press, Cambridge, Massachusetts.

Upton, C. and S. Bass. 1995. The Forest Certification Handbook. Earthscan Publications Ltd., London.

Vayda A.P. 1983. Progressive contextualization: methods for research on human ecology. Human Ecology 11: 265281.

Vayda A.P. 1996. Methods and Explanations in the Study of Human Actions and their Environmental Effects. CIFOR/WWF Special Publication, Bogor, Indonesia.

Vayda A.P., C.J. Pierce Colfer and M. Brotokusumo. 1980. Interactions between people and forests in East Kalimantan. Impact of Science on Society 30(3):179-190.

Wadley, R.L. 1997. Variation and changing tradition in Iban land tenure. Borneo Research Bulletin 28: in press.

Wadley, R.L. n.d. Iban agroforestry: Sustaining the long fallow. Paper presented at the ICRAF Workshop on Indigenous Strategies for Intensification of Shifting Cultivation in South-east Asia, June. Bogor, Indonesia. 
Wadley, R.L, C.J. Pierce Colfer and I.G. Hood. 1996. The role of sacred groves in hunting and conservation among the Iban of West Kalimantan, Indonesia. Paper presented at the 95th Annual Meeting of the American Anthropological Association, 20-24 November. San Francisco, California.

Wentzel, S. 1995. Main Results of the SFMP Social Forestry Field Study in the Area of the Three Partner Forest Enterprises (Feb - April 1995). Promotion of Sustainable Forest Management Systems (GTZ/BAPPEDA), Samarinda, Indonesia.

Wollenberg, E. 1996. Matrices prepared for inclusion in the Biodiversity Conservation Network's Studying the social dimensions of biodiversity conservation: strategies, approaches, methods, and resources.

Wollenberg, E. and C.J. Pierce Colfer. 1996. Social sustainability in the forest. ITTO Newsletter 6(2): 9-11.

Young, G.L. 1992. Between the atom and the void: hierarchy in human ecology. Advances in Human Ecology 1: 119-147.

Zweede, J. with J. Kressin, R. Mesquita, J. Natalino, M. Silva, V, M. Viana and C. Colfer. 1996. Final report: test Brazil, October 22 - November 21, 1995. (R. Prabhu and L.C. Tan, eds) CIFOR Project document. Bogor, Indonesia. 


\section{Appendix A \\ "Iterative Continuum Method" Form}

"Security of Inter-generational access to resources"

secure

insecure

Consider at least security of land/tree tenure, of use rights, of employment, of other possible forest-benefit-sharing mechanisms, for self and for children in the future. 


\section{Appendix B \\ Preliminary Steps to Sustainability Security of Inter-generational Access to Resources ${ }^{29}$}

Access to resources $(0=$ maximally unsustainable; $10=$ sustainable $)$

0 - a community scheduled for resettlement; victims of war; a community where no accessible resource base remains [parts of the Sahel]

1 - a community being invaded by victims of war or other in-migrants, with resulting competition and over-use of resources [parts of Côte d'Ivoire; Brazil]

2 - a community whose natural population growth and resource use patterns are threatening their own future access to resources [parts of Côte d'Ivoire]

3 - a community where neither local nor national law and practice are adequate to ensure access to resources by community members [imaginary]

4 - a community where individuals select elements from both local and national law and practice, in their own respective interests [Cameroon - as suggested by Alain Karsenty]

5 - a community with its rights of access protected by local law and practice, in conflict with national or other law and practice [Borneo]

6 - a community with its rights of access protected by all relevant law and practice, but where sustainability of the resource (including biodiversity) is in question [Quilcene, Washington, USA]

7 - a community with its rights of access protected by all relevant law and practice, with resources so abundant that people continue to have access (and biodiversity is maintained) even though current use would otherwise be unsustainable [British Columbia]

$8-$

9 - a community with its rights of access securely protected by law and practice, and mechanisms in place which insure the sustainability of the resource [perhaps Finland? Austria?]

$10-$

29 This set of steps is, as mentioned before, rather ad hoc. Ideally, rather than cases, we would extract the critical factors or variables that represent improvements in sustainability, with their trajectories. We are not yet able to do that, though Prabhu and Colfer plan to devote some time to this endeavour over the next year. 


\section{Appendix C \\ Cases Serving as Evidence in the Assessment of Security of Inter-generational Access to Resources}

In this appendix, (C) refers to a criterion and (I) to an indicator. Each indicator is numbered consecutively within each criterion. Numbered cases are presented under each indicator. Colfer and Wadley scored each case. Although Wadley saw Colfer's scoring before he did his own, he made every effort to score according to his own views. These scores have been averaged by Indicator in Table 6 .

\section{(C) 1: Local management is effective in controlling maintenance of and access to the resource}

(I) 1.1 Ownership and use rights to resources (inter- and intra-generational) are clear and respect pre$\underline{\text { existing claims }}^{30}$

1. Ng. Kedebu', Bukit Rancong and Danau Seluang residents have permission to reside in the Lakes area from their respective "mother villages" on the Kapuas. None has been permanently inhabited for more than a few decades, and many residents of all three communities are seasonal. On the other hand, each community has its fairly clearly, albeit extra-legally, defined territory (as shown in Figure 1).

$\mathrm{C}=7 ; \mathrm{W}=7$ (Melayu)

2. Wong Garai has lost effective control over large portions of their traditional territories (see Figure 4). Their small numbers have not required constant use of the entire area; and their ethic of generosity has prompted them to allow others to settle on their land in the past. This reduction in territory is not accompanied by any sense of animosity toward the people now occupying that land, who are by and large relatives, or historically connected to the people of Wong Garai (i.e., not outsiders).

$\mathrm{C}=5 ; \mathrm{W}=5$ (Iban)

3. In 1989, Wong Garai was able to save a significant tract of old growth forest from being logged. Wong Garai territory falls within the P.T. Militer concession, but the people appealed to the district and regional governments and received important help from one of their own who was a member of the regency legislature at the time. The forest was declared a protected area by the regency head (see Colfer and Wadley 1996).

$\mathrm{C}=7 ; \mathrm{W}=7$ (Iban)

4. Kelayang residents gave permission for a Melayu community to reside on Kelayang land some time ago. The Melayu community has recently been trying to claim the land as its own, including making official requests to local government officials. So far Kelayang has been able to resist the claim. The Melayu community relates to the administrative boundaries of the modern district of which they are part, whereas the Iban refer to their traditional system (old longhouse sites and cemeteries serve as evidence of their rights).

$\mathrm{C}=3 ; \mathrm{W}=3$ (Iban; Melayu)

5. By 1996 Bemban, in co-operation with other Iban communities and their leader in the district capitol of Badau, had succeeded in persuading the managers of a plantation and a concession (both far along in the planning and early implementation stages by 1993) to abandon their plans to work in Bemban territory (partly related to local claims for compensation ${ }^{31}$ related to pulau, protected forest groves, and tembawai, previous longhouse sites). $\mathrm{C}=6 ; \mathrm{W}=6$ (Iban)

30 Our emphasis here is on local ownership and use rights, but we might add that there is considerable difference of opinion about actual rights to resources, with local people feeling the resources belong to them, and the Government considering the resources to belong to the Nation.

31 Compensation was reportedly claimed and received in the amount of Rp. 20,000,000 (roughly US\$ 8,500), based on losses of fruit trees, determined by adat (or local customary law). 


\section{Box A1: Communities and Loggers in Competition}

In April 1996, the people of Bakakak (Melayu) burned down a base camp in territory they considered theirs, where P.T. Hutan Hebat had begun logging. The people claimed this area as a "protected area" from which they expected to harvest wood for their current and future building needs. The Regional Forestry Office in Pontianak had given Hutan Hebat special permission to cut in this area (which was in fact outside the company's current annual work area or "RKT"). There had been discussion between the company and community, in which the community had asked for company contributions which the company felt were excessive. Estimates of the requests ranged from Rp. 10 to 30 million [US\$4,300 to US\$12,800]. The community had not yet agreed to Hutan Hebat's cutting when the company began its logging operation. The burning appeared to be a spontaneous, village-wide reaction, reflecting people's feeling that Hutan Hebat was infringing on their legitimate rights.

There was an investigation involving the police, the military, the regional government, as well as the company and the community; and Hutan Hebat stopped cutting temporarily. However, our last understanding was that the Regional Forestry Office had stuck by its original permission, and the other governmental agencies were supporting Hutan Hebat. Hutan Hebat agreed to improve the boardwalks and build a religious school in the community. A local Forestry official said this action was not a requirement; only a "token of good will." The people, it appeared, had lost their right to the area they had been managing for their own future use. $\mathrm{C}=2 ; \mathrm{W}=2$ (Melayu)

6. Bemban was legally defined as part of the Melayu community of Pulau Duri' in 1989. Since that time, Pulau Duri' has tried to convert to ownership their freely granted use rights in agricultural land in Bemban's traditional area (lent to Pulau Duri' on a long-term basis). So far Bemban has successfully resisted this attempt to confiscate part of their traditional area.

$\mathrm{C}=7$ (Iban); $\mathrm{C}=2 ; \mathrm{W}=2$ (Melayu)

\section{(I) 1.2 Rules and norms of resource use are monitored and enforced ${ }^{32}$}

1. Ng. Kedebu' residents expressed "righteous anger" at other nearby communities whose members came and collected rattan or caught fish in their territory, contrary to $\mathrm{Ng}$. Kedebu' regulations.

$\mathrm{C}=7 ; \mathrm{W}=7($ Melayu $)$

2. A logging crew, that had not asked permission, was discovered in Bemban's territory. On July 1, all the village men went together, first to Pulau Duri' (where the official village headman lived) and then on to the camp in the forest, to question the intentions of the logging crew.

$\mathrm{C}=5 ; \mathrm{W}=5$ (Iban)

3. A group of Bemban children and young women went out to the tembawai (previous longhouse site) to collect ferns for supper. They explained that only people from the community could collect ferns in this area. A young girl took the jackfruit Colfer was carrying, saying that Colfer might be fined for taking the fruit, whereas she was allowed to do so (see Sandin 1980).

$\mathrm{C}=8 ; \mathrm{W}=8$ (Iban)

4. In 1994, residents of Wong Garai noticed members of another longhouse making moves to begin farming on Wong Garai's lowland swamp forests. Although the other longhouse had been given limited swamp land in the past, some people were attempting to expand their holdings without permission. A hearing at Wong Garai was called, and a major dispute was avoided with the other people withdrawing their intent to farm that forest (see

32 Again, our emphasis is on local rules and regulations. But there is a host of rules and regulations from different parts of the Ministry of Forestry which are not normally monitored or enforced (e.g., the government forester who neither knew the regulations on timber harvesting nor who was supposed to enforce them; or Conservation Project personnel who manage the Wildlife Reserve but regularly ignore Purple Herons and Storm's Storks tied to Melayu rafts, or Macaques and small birds kept as pets by the Iban. 


\section{Box A2: Enforcement of Regulations in the DSWR Fisheries}

In Danau Seluang, we learned of a representative conflict which captures Melayu problems with enforcement. Two nearby communities were situated on a common lake. One of the communities, Tayak, had regulations which they enforced against the use of jermal padat (a controversial, fine-meshed funnel net, see Giesen 1987; Dudley 1996a, 1996b) in their territory; the other community, Dayong, allowed use of jermal padat. Tayak complained to the authorities, citing prohibition on use of the nets from the governor, the regent, the county officials, as well as a treaty signed by all DSWR communities and many surrounding it in 1994, promising not to use poison, electric fishing or jermal padat in the lakes area.

A meeting was held in Tayak in June 1996, which head fishermen from five fishing communities, heads of five villages, county officials and representatives of Fisheries, the Military and the Police all attended. At this meeting, although everyone agreed that the nets were a) undesirable from the perspectives of sustainable fisheries and equity, and b) prohibited by a variety of supposed managers, no conclusion could be reached. Why? Because the people of Dayong had a written permit from the Fisheries Department, for which they had paid Rp. 30,000, to use jermal padat.

When the county commissioner was asked why no conclusion had been reached, he said that the government didn't have a legal leg to stand on, since another Government department had given permission and the jermal owner had paid for a licence. When the Fisheries Department personnel were asked the same question, they looked uneasy, saying that this was an inter-community boundary dispute, over which the Fisheries Department had no authority. [Excerpted from Colfer and Wadley 1996]

$\mathrm{C}=4 ; \mathrm{W}=4$ (Melayu)

Wadley 1997). Since then, people of Wong Garai have expressed their need and desire to preserve their lowland swamp forests for their own use in the future. ${ }^{33}$

$\mathrm{C}=9 ; \mathrm{W}=9$ (Iban)

5. Occasionally during the early 1990s, the people of Wong Garai have been approached by outsiders requesting permission to search for garu or aromatic eaglewood (Aquilaria spp.) in Wong Garai forests. Invariably, and despite misgivings, the Iban have granted access to their forests, occasionally joining the search, with the promise of recompense (fees, sharing of harvest or purchase). Also invariably, the community felt cheated, and complained amongst themselves (that some garu was hidden, or the work was harder than payments justified). Although this suggests naiveté on the part of the Iban to outsiders, it actually represents a deeply felt ethic of generosity and hospitality, making refusal extremely difficult (see Peluso 1994, Colfer et al. (1997), for a similar pattern among other Dayaks).

$\mathrm{C}=4 ; \mathrm{W}=4$ (Iban)

\section{(I) 1.3 Means of conflict resolution function without violence}

1. In the late 1980s, Wong Garai had a land dispute with a neighbouring longhouse. In years past, Wong Garai had allowed members of the other longhouse to farm land within Wong Garai territory, but later the other longhouse claimed the land as their own. They brought the case before the temenggong (traditional law leader) for a hearing, and the temenggong decided that the two disputants should divide the land. Wong Garai refused to accept the decision (which is locally agreed to be their right), arguing that the other longhouse has no tembawai (old longhouse sites) on Wong Garai territory which would mark their claim to the land. [See also (I)1.2, case 4] $\mathrm{C}=8 ; \mathrm{W}=8$ (Iban)

2. Ng. Kedebu' residents had frequent disagreements with P.T. Hutan Hebat, a timber company which regularly towed log rafts through $\mathrm{Ng}$. Kedebu' territory. One community member served as a tugboat pilot for the company, and also as an informal mediator in resolving these disputes. There was grumbling with regard to levels of compensation for damage to local fishing gear, but the system seemed to work.

$\mathrm{C}=8 ; \mathrm{W}=8$ (Melayu)

33 One impetus for this may be the ever-increasing threat of transmigration into the area down-river from Wong Garai - 200 families from Java. 
3. In 1994, several Iban merchants used large quantities of commercial pesticides to produce a major fish kill, for sale in Malaysia. This event killed hundreds of cages of fish which Ng. Kedebu' (and other) community members kept as "savings accounts" all along the Tawang river. Local ire was so great that the Conservation Project, local and regional government officials, the police and the military got involved in resolving the dispute. Ultimately all the communities in and around DSWR signed a pact not to use poison (see Box A2).

$\mathrm{C}=4 ; \mathrm{W}=4$ (Melayu)

4. Danau Seluang residents told a story from 1982-83, when Iban living up-river from Danau Seluang used fish poison eleven times. ${ }^{34}$ Each time the people complained and reported it to the authorities; no action was taken. This finally prompted the community to poison fish themselves, in retribution. This in turn prompted governmental action, and resulted in a reduction in fish poisoning for a while.

$\mathrm{C}=6 ; \mathrm{W}=6$ (Iban, Melayu)

5. See Box A1

$\mathrm{C}=2 ; \mathrm{W}=2$ (Melayu)

\section{(I) 1.4 Access to forest resources is perceived locally to be fair}

1. In Ng. Kedebu', logs had recently been quietly removed from passing P.T. Hutan Hebat log rafts. The logs were to be sawn into lumber and used to build a mosque. This action was agreed to by community members and justified with reference to the profits being gained by timber companies, vis-à-vis local benefits from local resources.

$\mathrm{C}=2 ; \mathrm{W}=2$ (Melayu)

2. Forest fires occurred extensively in 1992 (the last really dry year) in Danau Seluang's territory. This resulted in a significant reduction in the availability of rattan and timber, and losses connected with about 500 wooden tikung which serve as artificial bees' nests. Burning was variously described as purposeful and related to outsiders' envy or anger because they were denied permission to harvest; or entirely due to carelessness. $\mathrm{C}=3 ; \mathrm{W}=3$ (Melayu)

3. See also (I) 1.2 , Case 5 . $\mathrm{C}=4 ; \mathrm{W}=4$ (Iban)

4. Among the Melayu communities, use of jermal padat is considered unfair. The nets are large and expensive, and only a few residents have the means to buy them. Furthermore, they are efficient in catching fish, reducing the amount available for other fishers with access only to more labour-intensive fishing techniques. $\mathrm{C}=2 ; \mathrm{W}=2$ (Melayu)

\section{(I) 1.5 Local people feel secure about access to resources}

1. Wong Garai shares access to some forest and riverine land with another longhouse. There is some concern that this is leading to over-exploitation particularly of riverine resources (e.g., fish). People are also concerned about their future ability to collect fish in the Lakes area during the dry season - something they have been doing for at least 150 years and to which they make traditional use claims - given the increasing presence of Melayu in traditional Iban use areas and the possibility that the government will begin to enforce its own very different boundaries, in the future.

$\mathrm{C}=5 ; \mathrm{W}=5(\mathrm{Iban})$

2. In early 1994, the Wong Garai headman received a letter from the district office in Lubok Rian, explaining that there would be military people passing through the area doing a large mapping project for all the border districts. About a month later, soldiers came to Wong Garai territory, ferried in on helicopters to an open site some distance from the longhouse. The soldiers stayed for a few days in the forest, never making contact with the longhouse. Wong Garai residents were upset about this as it is locally regarded as a breach of common cour-

34 Wadley points out that there may have been conflicting perceptions of traditional use rights, with the Iban in question quite possibly considering this their right. Similar differences of opinion are quite possible in many of these cases. 


\section{Box A3: Compensation Paid to Communities}

In early 1996, an irrigation project was started on Wong Garai land that would feed down-river into the fields of other communities and a planned transmigration project. ${ }^{35}$ Wong Garai had successfully lobbied to get the main irrigation dam built within its territory, but when the site was surveyed and work started, project workers did not notify the longhouse. Banana trees and cassava plants in one garden at the site were cut down, and some graves in an old forest cemetery were disturbed with digging and tree felling. A number of Wong Garai women were first to see the work. They directly challenged the workers, forcing them to stop. After holding a traditional dispute hearing at the longhouse, the construction company was fined $>$ Rp. 500,000 (US\$212), ${ }^{36}$ which was divided with two other longhouses that had ancestors buried in the disturbed cemetery. The company was also required to pay for local rock and sand used in the dam and canal construction.

$\mathrm{C}=5 ; \mathrm{W}=5$ (Iban)

tesy. They viewed such lack of concern for proper etiquette as a sign of arrogance and as a reflection of their own powerlessness in the situation.

$\mathrm{C}=4 ; \mathrm{W}=4$ (Iban)

3. Throughout the DSWR area, concern is expressed that others (e.g., timber companies, other ethnic groups, transmigrants) are encroaching on their areas of traditional use, which could threaten their ability to use those resources in the future. For the Iban, the concern is more about their forest resources; whereas for the Melayu the concern revolves around fisheries resources.

$\mathrm{C}=4 ; \mathrm{W}=4$ (Iban; Melayu)

4. In Bemban, Ng. Kedebu' and Kelayang, many people expressed the conviction that they had recognised and legitimate rights to the areas and resources they were using - despite the presence of other stakeholders (especially the Conservation Project and timber companies) who were in competition for those resources.

$\mathrm{C}=8 ; \mathrm{W}=8$ (Iban; Melayu)

\section{(C) 2: Forest actors have a reasonable share in the economic benefits derived from forest use}

\section{(I) 2.1 Opportunities exist for local people/forest-dependent people to get employment and training from} forest companies

1. Very few residents within and around DSWR work for the timber concessions. Most workers are brought in from the outside. Kelayang is in the P.T. Panggau Libau concession, partially owned by Iban from the Lubok Rian area, some of whom are related to Kelayang residents. Although Kelayang economic involvement with this company is greater than that found between other companies (like P.T. Militer or P.T. Hutan Hebat) and local communities, there are still recurring conflicts (see Colfer and Wadley 1996). These include perceptions of inadequate employment opportunities, promised but unpaid rent on land, requests for rattan which is then not bought and unfair recompense when a community member was killed by a company speedboat. $\mathrm{C}=3 ; \mathrm{W}=3$ (Iban)

35 "Transmigration " is an Indonesian, government-sponsored programme to move people from densely populated areas (such as Java) to less-densely populated areas (such as Kalimantan).

36 Some fines and costs to the company included Rp. 300,000 for bothering the orchard, Rp. 200,000 for not reporting their activi-

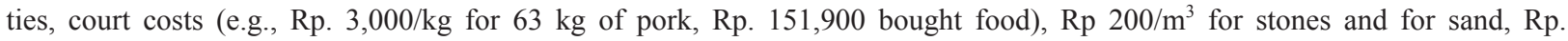
$25,000 /$ tree for each full-grown rubber tree destroyed (with varying prices depending on the size); Rp. 90,000 for each full-grown tengkawang tree, etc. (1996 exchange rate: US\$1 = Rp. 2350). 
2. In Ng. Kedebu', only one person is considered to have had a long-term relationship with the timber company. Young men occasionally work for a while with timber companies, but the perception of some is that when fishing is good, the young men will leave the company. This may mean that incomes from fishing (and related economic endeavours) are better than incomes from the company.

$\mathrm{C}=2 ; \mathrm{W}=2$ (Melayu)

3. See also (I) 2.3, Case 1.

$\mathrm{C}=2 ; \mathrm{W}=2$ (Melayu)

\section{(I) 2.2 Damages are compensated in a fair manner}

1. In 1992, a sub-contractor with P. T. Militer/P.T. Hutan Hebat paid Bemban one portable, 500-watt generator for the right to harvest an unknown number of hectares in Bemban's traditional area. The situation outlined in the Box A3 describes another example. Local people are becoming more astute, though they often lack power and voice in demanding justice.

$\mathrm{C}=2 ; \mathrm{W}=2$ (Iban)

\section{(I) 2.3 Wages and other benefits conform to national and/or ILO standards}

1. The workers Colfer spoke with - a mixture of locals and newcomers - considered themselves to be reasonably well paid, with reasonable benefits, working conditions and safety standards. ${ }^{37}$ On the other hand, Wadley found that Iban who have worked for Indonesian logging companies generally complain about the low wages locally (compared to what they could earn for comparable work in Malaysia), the dangerous conditions and poor equipment. Quite a few from Wong Garai had worked for P.T. Panggau Libau and said they had never been paid and would never work there again.

$\mathrm{C}=2 ; \mathrm{W}=2$ (Iban)

\section{(I) 2.4 Fair mechanisms exist for sharing benefits with local communities}

1. In Ng. Kedebu' and Bukit Rancong, there was a feeling that funds made available to the Conservation Project from eco-tourists and payment of salaries and other in-kind help from the project were unfairly distributed. $\mathrm{C}=2 ; \mathrm{W}=2$ (Melayu)

2. Payment of royalties to local communities, in recognition of their prior rights, has been suggested by some as a mechanism for sharing benefits more fairly. No royalties are paid to DSWR communities or those in the surrounding area. Various taxes are paid by companies to the Kapuas-based forestry agent, but these go to Pontianak (and a proportion also goes on to Jakarta, cf. Ascher 1993).

$\mathrm{C}=2 ; \mathrm{W}=2$ (Melayu)

3. The Indonesian government requires that concessionaires implement HPH Bina Desa, or a "village guidance" programme. This is designed to occur in a participatory manner, and can include income-generating projects, village structural improvements, agricultural improvements, contributions to education, religion or other community services (cf. Wentzel 1995). P.T. Panggau Libau (partially owned by local Iban - a situation unique in our experience) provided us with a listing of churches and schools they had built, teachers' salaries they had paid, and so on. Despite this, there were significant complaints about the company's activities, from Kelayang (see above; and from Wadley's previous work, from other communities as well). Most people queried, throughout the reserve and its surroundings, had never heard of HPH Bina Desa; the responses of the few who had (one of the district officers, an official in a timber concession) made it clear that the activity level was minimal. $\mathrm{C}=4 ; \mathrm{W}=4$ (Iban, Melayu)

37 As with the perception of security of tenure, local workers may have different perceptions than outside assessors. Local working conditions would not, for instance, comply with those proposed by previous CIFOR teams, or with ILO standards. 


\section{(C) 3: People link their and their children's future with management of forest resources}

\section{(I) 3.1 People invest in their surroundings (time, effort, money, etc.)}

1. Recent building of numerous schools and mosques in DSWR area. $\mathrm{C}=10 ; \mathrm{W}=10$ (Melayu)

2. Enforcement of local regulations to protect resources. For the Melayu, this involves protecting special areas such as fish nurseries; prohibiting small mesh sizes and harvesting of fish under certain size; restricting access to rattan or valuable wood; outlawing burning; and for the Iban, maintenance of special forest preserves (pulau) and old longhouse sites (tembawai), and the prohibition against farming the peaks of mountains to allow for forest regeneration of swiddens (see Wadley et al. 1996).

$\mathrm{C}=10 ; \mathrm{W}=10$ (Iban); $\mathrm{C}=8$ (Melayu)

3. Increasing educational levels (with significant sacrifice and investment by both parents and children). This also has recognised and profound negative consequences, such as loss of traditional ecological land ritual knowledge, devaluing of traditional work and knowledge, and increased consumerism.

$\mathrm{C}=6 ; \mathrm{W}=6$ (Iban; Melayu)

\section{(I) 3.2 Out-migration levels are low}

1. There is seasonal migration into the Reserve, primarily from residents along the Kapuas with kinship links to the communities within the Reserve. The close economic and kinship ties between Reserve communities and their "mother villages" along the Kapuas would make control of this seasonal population increase difficult as well. Many of those who started as seasonal fishers in the Reserve have settled in and built permanent homes there. Many also express a commitment to staying and making their community better for their children.

$\mathrm{C}=5 ; \mathrm{W}=5$ (Melayu)

2. Iban men are regular circular migrants to Malaysia where they work for the higher wages available there. They normally return home, bringing welcome booty with them (often at harvest time).

$\mathrm{C}=5 ; \mathrm{W}=5$ (Iban)

3. Permanent out-migration does not appear to be common. There are numerous examples of young people who have gone away to school and returned; and middle-aged people who have gone away to work for a while but returned to contribute their new abilities and experience to their home community.

$\mathrm{C}=7 ; \mathrm{W}=7$ (Iban; Melayu)

\section{(I) 3.3 People recognise the need to balance numbers of people with natural resources}

1. Birth control has been widely accepted - often linked to resource use issues. Iban women, however, recognising that families are better able to provide for fewer children, that they are freed from the real risk of death in pregnancy and childbirth, and that they can be more economically productive, worry that low or stable fertility levels among indigenous people like themselves may provide an excuse to move transmigrants into the area who may overwhelm them numerically.

$1 \mathrm{C}=7 ; \mathrm{W}=7$ (Iban)

2. There appears to be considerable in-migration into the Reserve, with no effort or means to control it. Indeed, there is an ethic of hospitality which would make such control difficult without outside support.

$\mathrm{C}=3 ; \mathrm{W}=3$ (Melayu)

3. See also (I) 3.2 .

\section{(I) 3.4 Children are educated (formally and/or informally) about natural resource management}

1. Selection by parents of a variety of disciplines for their children to pursue (within one family) with the expectation that when the children return home, such knowledge will be available to the family and community from 
which they come. We met a number of examples of young people who did just that.

$\mathrm{C}=5 ; \mathrm{W}=5$ (Iban)

2. The Iban have a still-functioning system of land tenure and tree ownership rules and practice (see Wadley 1997), and maintain many rituals connected to farming. But they fear these "old ways" - the ritual chants, the rich ceremonial language, and farming and forest knowledge - are being lost to the youth. Competition from national education and television is constant. In June 1996, for example, a set of important longhouse rituals was being performed at 1 am (making of offerings, chanting of invocations to ancestor gods). At the same time, the young people had set up a stereo system to play Indonesian pop music at high volume, to which they "disco-ed" at the other end of the longhouse. The resources of cultural and ecological knowledge (integral to sustainable management) which their immediate and distant ancestors have acquired were being lost. $\mathrm{C}=4 ; \mathrm{W}=5$ (Iban)

\section{(I) 3.5 Destruction of natural resources by local communities is rare. ${ }^{38}$}

1. Recurrent poisoning of fish with commercial pesticides, largely by a minority of Iban merchants, but also by some Melayu.

$\mathrm{C}=4 ; \mathrm{W}=4$ (Iban; Melayu)

2. Use of jermal padat, by a few comparatively wealthy Melayu (under a schizophrenic government policy). $\mathrm{C}=3 ; \mathrm{W}=3$ (Melayu)

3. Perceived over-harvesting of swamp forest (rawa) by local people - current supplies of species available to local people are significantly reduced (tembesu', kawi, kelansau, medang, menyawai). [Those used by Melayu are mostly swamp species.]

$\mathrm{C}=5 ; \mathrm{W}=5$ (Melayu)

\section{(I) 3.6 People maintain spiritual links to the land}

1. During Colfer's brief stay in Kelayang, three resource-related religious ceremonies were observed, all of which included the active involvement of the young (one to "feed" a crocodile spirit in the river whose hunger had been revealed in a dream to constitute a threat to a community member; one to "feed" the soil before beginning to clear a ricefield; and one to "feed" the soil in preparation for planting).

$\mathrm{C}=10 ; \mathrm{W}=10$ (Iban)

2. Strong sense of history and location (among the Iban) and an explicitly stated sense of responsibility to provide for children, grandchildren and subsequent descendants.

$\mathrm{C}=8 ; \mathrm{W}=8$ (Iban)

3. Iban refer to the forest as seput menoa - "the breath of the land", and recognise the hydrological consequences of too much forest cutting - e.g., drying up of water sources. ${ }^{39}$ (See Wadley et al. 1996).

$\mathrm{C}=8 ; \mathrm{W}=8$ (Iban)

4. Ng. Kedebu' parents express their sense of responsibility to their descendants, including expressions of concern about the sustainability of resources that are important to their lifestyle (timber, fish, rattan, bees). $\mathrm{C}=5 ; \mathrm{W}=5$ (Melayu)

38 Other C\&I will have to deal with destruction by other stakeholders (e.g., harvesting of timber by concessionaires without regard to regulations; transmigration of large numbers of families into already occupied forest areas; conversion of natural forest areas to industrial timber estates or oil palm/rubber plantations).

39 This hydrological knowledge has a spiritual component in that Iban contend that if they do not take care of the land both ecologically and ritually, it and they will become threatened with supernatural "heat" (angat) which manifests itself in people's health and in social disruption. 